\title{
Effects of mineral dust on global atmospheric nitrate concentrations
}

\author{
V. A. Karydis ${ }^{1}$, A. P. Tsimpidi ${ }^{1}$, A. Pozzer ${ }^{1}$, M. Astitha ${ }^{2}$, and J. Lelieveld ${ }^{1,3}$ \\ ${ }^{1}$ Max Planck Institute for Chemistry, 55128 Mainz, Germany \\ ${ }^{2}$ Department of Civil and Environmental Engineering, University of Connecticut, Storrs, CT, USA \\ ${ }^{3}$ Energy, Environment and Water Research Center, The Cyprus Institute, 1645 Nicosia, Cyprus
}

Correspondence to: V. A. Karydis (v.karydis@mpic.de)

Received: 26 February 2015 - Published in Atmos. Chem. Phys. Discuss.: 20 April 2015

Revised: 7 December 2015 - Accepted: 27 January 2016 - Published: 10 February 2016

\begin{abstract}
This study assesses the chemical composition and global aerosol load of the major inorganic aerosol components, focusing on mineral dust and aerosol nitrate. The mineral dust aerosol components (i.e., $\mathrm{Ca}^{2+}, \mathrm{Mg}^{2+}, \mathrm{K}^{+}, \mathrm{Na}^{+}$) and their emissions are included in the ECHAM5/MESSy Atmospheric Chemistry model (EMAC). Gas/aerosol partitioning is simulated using the ISORROPIA-II thermodynamic equilibrium model that considers $\mathrm{K}^{+}, \mathrm{Ca}^{2+}, \mathrm{Mg}^{2+}$, $\mathrm{NH}_{4}^{+}, \mathrm{Na}^{+}, \mathrm{SO}_{4}^{2-}, \mathrm{NO}_{3}^{-}, \mathrm{Cl}^{-}$, and $\mathrm{H}_{2} \mathrm{O}$ aerosol components. Emissions of mineral dust are calculated online by taking into account the soil particle size distribution and chemical composition of different deserts worldwide. Presence of metallic ions can substantially affect the nitrate partitioning into the aerosol phase due to thermodynamic interactions. The model simulates highest fine aerosol nitrate concentration over urban and industrialized areas $\left(1-3 \mu \mathrm{g} \mathrm{m}^{-3}\right)$, while coarse aerosol nitrate is highest close to deserts (1$4 \mu \mathrm{g} \mathrm{m}^{-3}$ ). The influence of mineral dust on nitrate formation extends across southern Europe, western USA, and northeastern China. The tropospheric burden of aerosol nitrate increases by $44 \%$ when considering interactions of nitrate with mineral dust. The calculated global average nitrate aerosol concentration near the surface increases by $36 \%$, while the coarse- and fine-mode concentrations of nitrate increase by 53 and $21 \%$, respectively. Other inorganic aerosol components are affected by reactive dust components as well (e.g., the tropospheric burden of chloride increases by $9 \%$, ammonium decreases by $41 \%$, and sulfate increases by $7 \%$ ). Sensitivity tests show that nitrate aerosol is most sensitive to the chemical composition of the emitted mineral dust, followed by the soil size distribution of dust particles, the magnitude of the mineral dust emissions, and the aerosol state assumption.
\end{abstract}

\section{Introduction}

Atmospheric aerosols from natural and anthropogenic sources adversely affect human health and play an important role in changing the Earth's climate. Inorganic particulate nitrate constituents contribute significantly to the total aerosol mass, especially in urban areas and industrialized regions (Putaud et al., 2004; Kerkweg et al., 2007; Henze et al., 2009; Kopacz et al., 2010; Jöckel et al., 2010). Over Europe, particulate nitrate accounts for about $10-20 \%$ of the total dry aerosol mass (Putaud et al., 2004). Veefkind et al. (1996) suggested that nitrate is particularly important in the optically active submicron size range, related to its ability to efficiently scatter solar radiation and its potential to affect cloud properties. The Intergovernmental Panel on Climate Change (IPCC) also underscored the important role of nitrate aerosol in climate change (IPCC, 2013). However, there is large uncertainty regarding the global nitrate aerosol load, its regional distribution, and its radiative forcing. In fact, only a limited number of global models have been used to estimate particulate nitrate concentrations and their regional distributions (Adams et al., 1999; Metzger et al., 2002; Liao et al., 2003; Rodriguez and Dabdub, 2004; Feng and Penner, 2007; Pringle et al., 2010; Fairlie et al., 2010; Bellouin et al., 2011; Xu and Penner, 2012; Pozzer et al., 2012; Hauglustaine et al., 2014). In these studies, estimates of the nitrate aerosol tropospheric burden vary by 1 order of magnitude, ranging from 0.13 to $1.85 \mathrm{Tg}$.

One of the challenges in atmospheric aerosol modeling is to compute the partitioning of semi-volatile nitrate between the gas and aerosol phases. Nitrate aerosols in polluted regions are typically formed when sulfate aerosols are irreversibly neutralized and atmospheric ammonia is present in 
excess. Therefore, nitrate predominantly occurs in the fine mode, mainly observed in the form of ammonium nitrate at continental sites (ten Brink et al., 1997; Putaud et al., 2010). Many thermodynamic equilibrium models have been developed over the past decades that can accurately describe the formation of ammonium nitrate in the aerosol phase (i.e., AIM of Wexler and Seinfeld, 1991; SCAPE of Kim et al., 1993; EQUISOLV of Jacobson et al., 1996; ISORROPIA of Nenes et al., 1998; GFEMN of Ansari and Pandis, 1999). However, aerosol nitrate is not only associated with ammonium in the fine mode. Coarse-mode aerosol nitrate can be produced by adsorption of nitric acid on sea salt (Savoie and Prospero, 1982) and soil (Wolff, 1984) particles. In particular the light-metallic ions of calcium, magnesium, sodium, and potassium can be associated with nitrate and affect its partitioning into the aerosol phase. In order to account for the effect of crustal species on the partitioning of nitrate, mineral cations (i.e., $\mathrm{Ca}^{2+}, \mathrm{Mg}^{2+}, \mathrm{K}^{+}$) have been added to the suite of components of a few thermodynamic models i.e., SCAPE2 (Kim and Seinfeld, 1995), EQUISOLV II (Jacobson, 1999), EQSAM3 (Metzger and Lelieveld, 2007), ISORROPIA II (Fountoukis and Nenes, 2007).

Several studies in the past have shown that the simulation of these effects, especially in areas where dust or sea salt comprises a significant portion of total particulate matter, can considerably improve model predictions (Dentener et al., 1996; Gong et al., 1997; Jacobson, 1999; Jacob, 2000; Song and Carmichael, 2001; Moya et al., 2002; Bian and Zender, 2003; Laskin et al., 2005; Hodzic et al., 2006; Kallos et al., 2007; Astitha and Kallos, 2009; Athanasopoulou et al., 2008, 2010; Fountoukis et al., 2009; Karydis et al., 2010, 2011a; Tsyro et al., 2011; Wang et al., 2012; Im, 2013; Trump et al., 2015). According to their findings, including marine and crustal species in models can substantially affect the phase partitioning of nitrate aerosols. Few of these studies have applied a hybrid approach for aerosol thermodynamics, which combines the dynamic calculation of mass transfer to coarse-mode particles with an equilibrium approach for the fine-mode particles, and found that mineral dust and sea salt can considerably affect the size distribution of aerosol nitrate (Athanasopoulou et al., 2008, 2010; Karydis et al., 2010, 2011a; Trump et al., 2015). The presence of mineral cations can also affect the aerosol ammonium concentrations due to thermodynamic interactions with the remainder ions in the aqueous phase (Karydis et al., 2010, 2011a). Furthermore, heterogeneous chemistry occurring on dust particles can also act as a source for sulfate (Wang et al., 2012).

The thermodynamic interactions of crustal elements with inorganic aerosol components can be very important on a global scale, since mineral dust is a dominant compound in the atmosphere. Mineral dust accounts for more than $50 \%$ of the global aerosol load (Grini et al., 2005; Zender and Kwon, 2005) with $\mathrm{Ca}^{2+}, \mathrm{Mg}^{2+}, \mathrm{K}^{+}$, and $\mathrm{Na}^{+}$in the form of mineral cations being the major chemically active components (Sposito, 1989). Dust particles largely originate from the subtropi- cal deserts (Prospero et al., 2002) and can be transported over long distances and to high altitudes (Prospero et al., 2001; Kallos et al., 2007). The long-range transport of dust particles can influence the aerosol dynamics and atmospheric chemistry thousands of kilometers downwind of the source regions, while the chemical processing of the dust during transport can mobilize nutrients that are important for the marine biota (Solmon et al., 2009). Under favorable conditions, dust particles from the Sahara can travel across the Mediterranean Sea toward Europe (Mitsakou et al., 2008; Querol et al., 2009; Bangert et al., 2012) or across the Atlantic Ocean toward the Caribbean (Chiapello et al., 2005; Kallos et al., 2006) and South America (Formenti et al., 2001), while dust from the Gobi and Taklimakan deserts often crosses the Pacific and can reach the west coast of the Americas (Fairlie et al., 2010; Wang et al., 2012; Karydis et al., 2011b). The dust particles can substantially influence air quality (Giannadaki et al., 2014). Therefore, an accurate representation of mineral dust emissions, transport, composition, and chemistry is essential to minimize the nitrate-aerosol-related uncertainties in global chemistry-climate simulations.

However, most thermodynamic models used in global studies lack a realistic treatment of crustal species (Liao et al., 2003; Martin et al., 2003; Bauer et al., 2004; Koch et al., 2011; Leibensperger et al., 2012). Only a few global studies account for dust aerosol chemistry. Feng and Penner (2007) have included the heterogeneous reactions of $\mathrm{HNO}_{3}$ with $\mathrm{CaCO}_{3}, \mathrm{MgCO}_{3}, \mathrm{Na}_{2} \mathrm{CO}_{3}$, and $\mathrm{K}_{2} \mathrm{CO}_{3}$ into a three-dimensional aerosol and chemistry model to study the global distribution of nitrate and ammonium aerosol concentrations. Xu and Penner (2012) used the same model to explore the nitrate aerosol direct and indirect radiative forcing. Fairlie et al. (2010) have included the uptake of nitric acid on dust particles, limited by the dust alkalinity expressed as $\mathrm{Ca}^{2+}$, in a global chemical transport model to study the impact of mineral dust on nitrate in transpacific Asian pollution plumes. Hauglustaine et al. (2014) applied the same uptake parametrization in a global model to simulate present and future nitrate aerosols and their climatic impact. However, these studies assumed a globally uniform chemical composition and size distribution for mineral dust particles and have not addressed the effect of mineral dust on nitrate aerosol formation and its tropospheric burden.

The present work is a first attempt to assess the effect of naturally emitted dust particles on global nitrate aerosol concentrations and size distributions. We have used the ECHAM5/MESSy Atmospheric Chemistry (EMAC) model (Jöckel et al., 2006) to simulate the nitrate aerosol formation and size distribution. Nitrate interactions with mineral dust have been taken into account by using the thermodynamic equilibrium model ISORROPIA II (Fountoukis and Nenes, 2007). Dust emissions are calculated online by an advanced dust emission scheme (Astitha et al., 2012) which accounts for the soil particle size distribution of different deserts worldwide. Chemical compositions of the emitted 
dust particles compiled from the literature are adopted for the main deserts to study the chemical interaction among crustal and inorganic species. Furthermore, the sensitivity of the results to the emitted dust aerosol load, the size distribution of the soil particles, the mineral dust chemical composition, and the aerosol thermodynamic state is discussed.

\section{Global model description}

\subsection{EMAC model}

We used the ECHAM5/MESSy Atmospheric Chemistry (EMAC) model, which is a numerical chemistry and climate simulation system that includes submodels describing atmospheric processes from the troposphere to stratosphere and their interaction with oceans, land, and human influences (Jöckel et al., 2006). It uses the Modular Earth Submodel System (MESSy2) (Jöckel et al., 2010) to link the different submodels with an atmospheric dynamical core which is the 5th generation European Centre - Hamburg general circulation model (ECHAM5) (Roeckner et al., 2006). The EMAC model has been extensively described and evaluated against in situ observations and satellite measurements that include filter-based particulate matter concentrations, aerosol optical depth, acid deposition, gas-phase mixing ratios, and meteorological parameters, and can be applied at a range of spatial resolutions (Jöckel et al., 2006; Pozzer et al., 2006; de Meij et al., 2012; Pozzer et al., 2012). In this study, the spectral resolution of the EMAC model is T42L31, corresponding to a horizontal grid resolution of approximately $2.8^{\circ} \times 2.8^{\circ}$ and 31 vertical layers extending to $25 \mathrm{~km}$ altitude. EMAC is applied for 5 years covering the period 2004-2008 and the first year is used as spin-up.

The EMAC model calculates fields of gas-phase species online through the Module Efficiently Calculating the Chemistry of the Atmosphere (MECCA) submodel (Sander et al., 2011). MECCA calculates the concentration of a range of gases, including aerosol precursor species such as $\mathrm{SO}_{2}, \mathrm{NH}_{3}$, $\mathrm{NO}_{x}$, dimethyl sulfide (DMS), $\mathrm{H}_{2} \mathrm{SO}_{4}$, and DMSO. The concentrations of the major oxidant species $\left(\mathrm{OH}, \mathrm{H}_{2} \mathrm{O}_{2}, \mathrm{NO}_{3}\right.$, and $\mathrm{O}_{3}$ ) are also calculated online. The loss of gas-phase species to the aerosol through heterogeneous reactions (e.g., $\mathrm{N}_{2} \mathrm{O}_{5}$ to form $\mathrm{HNO}_{3}$ ) is treated using the MECCA_KHET submodel (Jöckel et al., 2010). The aqueous-phase oxidation of $\mathrm{SO}_{2}$ and the uptake of $\mathrm{HNO}_{3}$ and $\mathrm{NH}_{3}$ in cloud droplets are treated by the SCAV submodel (Tost et al., 2006, 2007).

Aerosol microphysics and gas/aerosol partitioning are calculated by the Global Modal-aerosol eXtension (GMXe) module (Pringle et al., 2010). The aerosol size distribution is described by seven interacting lognormal modes (four hydrophilic and three hydrophobic modes). The aerosol composition within each mode is uniform in size (internally mixed), though can vary between modes (externally mixed). The four hydrophilic modes are arranged to cover the aerosol size spectrum (nucleation, Aitken, accumulation and coarse). The three hydrophobic modes have the same size range, but no hydrophobic nucleation mode is required. Each mode is defined in terms of the number concentration, the number mean radius, and the geometric standard deviation $(\sigma)$ and has a fixed size boundary but a variable mean radius (Pringle et al., 2010). The removal of gas and aerosol species through wet deposition is calculated within the SCAV submodel (Tost et al., 2006), while dry deposition is calculated within the DRYDEP submodel (Kerkweg et al., 2006) based on the big leaf approach. The sedimentation of aerosols is calculated within the SEDI submodel (Kerkweg et al., 2006) using a first-order trapezoid scheme.

\subsection{Inorganic aerosol thermodynamics}

The inorganic aerosol composition is computed with the ISORROPIA-II thermodynamic equilibrium model (Fountoukis and Nenes, 2007). ISORROPIA-II calculates the gas/liquid/solid equilibrium partitioning of the $\mathrm{K}^{+}, \mathrm{Ca}^{2+}$, $\mathrm{Mg}^{2+}, \mathrm{NH}_{4}^{+}, \mathrm{Na}^{+}, \mathrm{SO}_{4}^{2-}, \mathrm{NO}_{3}^{-}, \mathrm{Cl}^{-}$, and $\mathrm{H}_{2} \mathrm{O}$ aerosol system. Potassium, calcium, magnesium, and sodium are considered as chemically active components of mineral dust and are assumed to exist in the form of 14 mineral salts in the solid phase $\left(\mathrm{Ca}\left(\mathrm{NO}_{3}\right)_{2}, \mathrm{CaCl}_{2}, \mathrm{CaSO}_{4}, \mathrm{KHSO}_{4}\right.$, $\mathrm{K}_{2} \mathrm{SO}_{4}, \mathrm{KNO}_{3}, \mathrm{KCl}, \mathrm{MgSO}_{4}, \mathrm{Mg}\left(\mathrm{NO}_{3}\right)_{2}, \mathrm{MgCl}_{2}, \mathrm{NaHSO}_{4}$, $\mathrm{Na}_{2} \mathrm{SO}_{4}, \mathrm{NaNO}_{3}, \mathrm{NaCl}$ ) and four ions in the aqueous phase $\left(\mathrm{Ca}^{2+}, \mathrm{K}^{+}, \mathrm{Mg}^{2+}, \mathrm{Na}^{+}\right)$. ISORROPIA-II solves for the equilibrium state by considering the chemical potential of the species and minimizes the number of equations and iterations required by considering specific compositional regimes. In ISORROPIA-II the aerosol can be in either a thermodynamically stable state (where salts precipitate once the aqueous phase becomes saturated) or in a metastable state (where the aerosol is composed only of a supersaturated aqueous phase). In this application we assume that aerosols can form solids (stable state) but we test the sensitivity of the results by using the metastable assumption as well.

The assumption of thermodynamic equilibrium is a good approximation for fine-mode aerosols that can reach equilibrium very fast. However, the equilibrium timescale for large particles is typically larger than the time step of the model (Meng and Seinfeld, 1996). To account for kinetic limitations, the process of gas/aerosol partitioning is calculated in two stages (Pringle et al., 2010). In the first stage the amount of the gas-phase species that is able to kinetically condense onto the aerosol phase within the model time step is calculated, assuming diffusion limited condensation (Vignati et al., 2004). In the second stage, ISORROPIA-II redistributes the mass between the gas and the aerosol phase, assuming instant equilibrium between the two phases. 
Table 1. Chemical composition of mineral dust.

\begin{tabular}{lccccll}
\hline & \multicolumn{6}{c}{ Crustal species } \\
\cline { 2 - 5 } Desert & $\mathrm{Na}^{+}$ & $\mathrm{K}^{+}$ & $\mathrm{Ca}^{2+}$ & $\mathrm{Mg}^{2+}$ & Other & Reference \\
\hline Great Basin & 0.064 & 0.023 & 0.053 & 0.018 & 0.842 & Fantle et al. (2012) \\
Mojave & 0.015 & 0.027 & 0.059 & 0.019 & 0.880 & Reynolds et al. (2006) \\
Sonoran & 0.025 & 0.012 & 0.037 & 0.006 & 0.920 & Kasper-Zubillaga and Zolezzi-Ruiz (2007) \\
Patagonia & 0.012 & 0.015 & 0.021 & 0.013 & 0.939 & Gaiero et al. (2007) \\
Monte & 0.023 & 0.018 & 0.025 & 0.009 & 0.925 & Tripaldi et al. (2010) \\
Atacama & 0.069 & 0.007 & 0.018 & 0.005 & 0.901 & Michalski et al. (2004) \\
Kalahari/Namibia & 0.030 & 0.050 & 0.120 & 0.090 & 0.710 & Resane et al. (2004) \\
Sahara & 0.011 & 0.035 & 0.075 & 0.030 & 0.849 & Formenti et al. (2008) \\
Saudi Arabia & 0.010 & 0.004 & 0.034 & 0.006 & 0.946 & Dada et al. (2013) \\
Thar/Lut & 0.022 & 0.033 & 0.082 & 0.022 & 0.841 & Yadav and Rajamani (2004) \\
Taklimakan & 0.012 & 0.030 & 0.120 & 0.028 & 0.810 & Zhang et al. (2003) \\
Gobi & 0.012 & 0.021 & 0.077 & 0.017 & 0.873 & Zhang et al. (2003) \\
Great Sandy/Simpson & 0.028 & 0.001 & 0.005 & 0.003 & 0.963 & Radhi et al. (2011) \\
Other & 0.012 & 0.015 & 0.024 & 0.009 & 0.940 & Sposito (1989) \\
\hline
\end{tabular}

\subsection{Dust emission scheme}

Dust emissions are calculated online by an advanced dust flux scheme developed by Astitha et al. (2012). The scheme uses the online meteorological fields from the EMAC model (temperature, pressure, relative humidity $(\mathrm{RH})$, soil moisture, and the surface friction velocity) together with specific input fields for soil properties (i.e., the geographical location of the dust sources, the clay fraction of the soils, the rooting depth, and the monthly vegetation area index) and calculates the dust emission fluxes online. The dust particles are considered to be mobilized in the atmosphere when the wind friction velocity, a proxy of the surface drag properties, exceeds a threshold value. This threshold value depends on the soil size distribution and soil texture classification. The emission scheme uses an explicit geographical representation of the emitted soil particle size distribution based on soil characteristics in every grid cell (Astitha et al., 2012). The total annual average global emission flux of dust particles is $5684 \mathrm{Tg} \mathrm{yr}^{-1}$. As a sensitivity study, an alternative dust emission scheme is used which utilizes a homogeneous global soil size distribution of dust particles and assumes that the emitted dust particles have the same size distribution in all grid cells based on D'Almeida (1987). In this case, the total annual average global emission flux of dust particles is $3660 \mathrm{Tg} \mathrm{yr}^{-1}$. Details about the online dust production schemes used in this study can be found in Astitha et al. (2012).

Emissions of individual crustal species $\left(\mathrm{Ca}^{2+}, \mathrm{Mg}^{2+}, \mathrm{K}^{+}\right.$, $\mathrm{Na}^{+}$) are estimated as a constant fraction of mineral dust emissions. This fraction is determined based on the geological information that exists for the different dust source regions of the planet and is applied online on the calculated mineral dust emissions based on the location of the grid cell. Table 1 lists the chemical composition of mineral dust used in

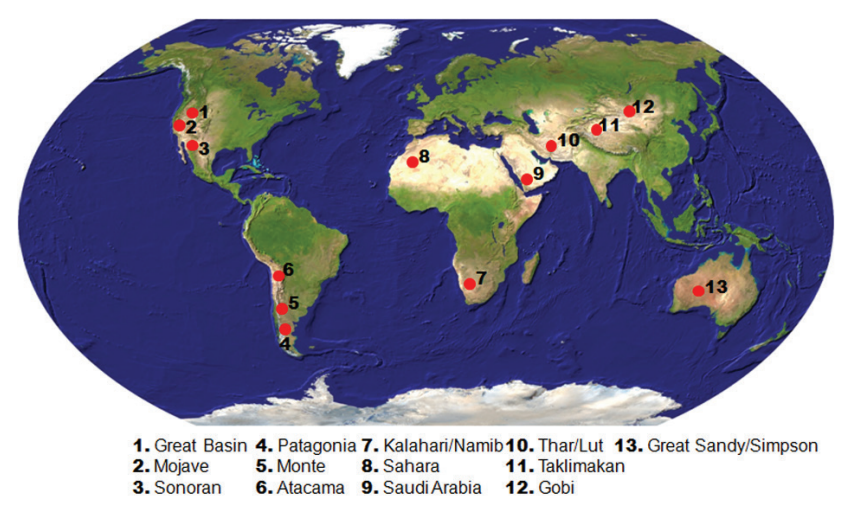

Figure 1. Location of the main desserts of the world in which a discrete chemical composition of the emitted mineral dust is used.

this study for the main deserts of the world (Fig. 1) based on the cited literature. As a sensitivity study, a spatially uniform mineral dust composition is also used by assuming a global emission ratio between crustal species and dust of 1.2, 1.5, 2.4, and $0.9 \%$ for $\mathrm{Na}^{+}, \mathrm{K}^{+}, \mathrm{Ca}^{2+}$, and $\mathrm{Mg}^{2+}$, respectively, based on Sposito (1989).

\subsection{Aerosol precursor and sea salt emissions}

Fuel-combustion-related and agriculture-related emissions of $\mathrm{NO}_{x}, \mathrm{NH}_{3}$, and $\mathrm{SO}_{2}$, which represent the gaseous precursors of the major inorganic components, are based on the high-resolution $\left(0.1^{\circ}\right)$ global anthropogenic emission inventory applied at monthly intervals, EDGAR-CIRCE (Doering et al., 2009). The anthropogenic emissions are distributed vertically as described in Pozzer et al. (2009). The natural emissions of $\mathrm{NH}_{3}$ are based on the GEIA database (Bouwman et al., 1997) and include excreta from domestic animals, wild animals, synthetic nitrogen fertilizers, oceans, biomass 
Table 2. Statistical evaluation of EMAC-simulated aerosol concentrations against monthly average observations from Europe during 20052008.

\begin{tabular}{lcrrrrrrr}
\hline $\begin{array}{l}\text { EMEP network } \\
\text { Metric }\end{array}$ & $\mathrm{NO}_{3}^{-}$ & $\mathrm{Na}^{+}$ & $\mathrm{Ca}^{2+}$ & $\mathrm{K}^{+}$ & $\mathrm{Mg}^{2+}$ & $\mathrm{NH}_{4}^{+}$ & $\mathrm{Cl}^{-}$ & $\mathrm{SO}_{4}^{2-}$ \\
\hline Observed $\left(\mu \mathrm{g} \mathrm{m}^{-3}\right)$ & 0.36 & 0.91 & 0.13 & 0.11 & 0.09 & 0.72 & 1.31 & 0.64 \\
Calculated $\left(\mu \mathrm{g} \mathrm{m}^{-3}\right)$ & 1.24 & 0.65 & 0.12 & 0.06 & 0.1 & 1.04 & 1 & 2 \\
MAGE $\left(\mu \mathrm{g} \mathrm{m}^{-3}\right)$ & 0.91 & 0.45 & 0.07 & 0.06 & 0.06 & 0.43 & 0.59 & 1.34 \\
MB $\left(\mu \mathrm{g} \mathrm{m}^{-3}\right)$ & 0.88 & -0.26 & -0.01 & -0.05 & 0.01 & 0.32 & -0.31 & 1.33 \\
$\mathrm{NME}$ & 1.98 & 0.49 & 0.57 & 0.55 & 0.66 & 0.6 & 0.45 & 1.77 \\
$\mathrm{NMB}$ & 1.83 & -0.01 & -0.01 & -0.35 & 0.46 & 0.33 & -0.24 & 1.75 \\
RMSE $\left(\mu \mathrm{g} \mathrm{m}^{-3}\right)$ & 0.96 & 1.72 & 0.13 & 0.11 & 0.08 & 0.79 & 0.67 & 1.36 \\
Number of comparisons & 1455 & 1121 & 1479 & 1400 & 1266 & 1450 & 423 & 2792 \\
\hline
\end{tabular}

burning, and emissions from soils under natural vegetation. $\mathrm{NO}_{x}$ produced by lightning is calculated online and distributed vertically based on the parameterization of Price and Rind (1992). The emissions of NO from soils are calculated online based on the algorithm of Yienger and Levy (1995). Eruptive and non-eruptive volcanic degassing emissions of $\mathrm{SO}_{2}$ are based on the AEROCOM data set (Dentener et al., 2006). The oceanic DMS emissions are calculated online by the AIRSEA submodel (Pozzer et al., 2006). The total global, annual average emissions of $\mathrm{NO}_{x}, \mathrm{NH}_{3}$, and $\mathrm{SO}_{2}$ are 51, 65 , and $65 \mathrm{Tg} \mathrm{yr}^{-1}$, respectively. More details about the gasphase emissions used by EMAC can be found in Pozzer et al. (2012). Emissions of sea spray aerosols are based on the offline monthly emission data set of AEROCOM (Dentener et al., 2006), assuming a composition of $55 \% \mathrm{Cl}^{-}, 30.6 \%$ $\mathrm{Na}^{+}, 7.7 \% \mathrm{SO}_{4}^{2-}, 3.7 \% \mathrm{Mg}^{2+}, 1.2 \% \mathrm{Ca}^{2+}$, and $1.1 \% \mathrm{~K}^{+}$ (Seinfeld and Pandis, 2006). The total global emission flux of sea spray aerosols is $5910 \mathrm{Tg} \mathrm{yr}^{-1}$.

\section{Model evaluation}

Tables 2, 3, and 4 include the comparison of model predictions of aerosol nitrate, sulfate, chloride, sodium, calcium, magnesium, and potassium concentrations with measurements from the European Monitoring and Evaluation Programme (EMEP; http://nilu.no/projects/ccc/emepdata.html), the Clean Air Status and Trends Network (CASTNET; http: //www.epa.gov/castnet), and the Acid Deposition Monitoring Network in East Asia (EANET; http://www.eanet.asia/ product/index.html). The data selected for the evaluation are averaged monthly during the simulation period 20052008. The mean bias (MB), mean absolute gross error (MAGE), normalized mean bias (NMB), normalized mean error (NME), and the root mean square error (RMSE) were calculated to assess the model performance:

MAGE $=\frac{1}{N} \sum_{i=1}^{N}\left|P_{i}-O_{i}\right| \quad \mathrm{MB}=\frac{1}{N} \sum_{i=1}^{N}\left(P_{i}-O_{i}\right)$
$\mathrm{NME}=\frac{\sum_{i=1}^{N}\left|P_{i}-O_{i}\right|}{\sum_{i=1}^{N} O_{i}} \quad \mathrm{NMB}=\frac{\sum_{i=1}^{N}\left(P_{i}-O_{i}\right)}{\sum_{i=1}^{N} O_{i}}$

$\operatorname{RMSE}=\left[\frac{1}{N} \sum_{i=1}^{N}\left(P_{i}-O_{i}\right)^{2}\right]^{\frac{1}{2}}$,

where $P_{i}$ is the predicted value of the pollutant concentration, $O_{i}$ is the observed value of the pollutant at the same monthly averaged time, and $N$ is the total number of data points used for the comparison. NME and MAGE (in $\mu \mathrm{g} \mathrm{m}^{-3}$ ) provide an assessment of the overall discrepancy between model predictions and observations, while NMB and MB (in $\mu \mathrm{g} \mathrm{m}^{-3}$ ) are indicative of systematic errors. RMSE (in $\mu \mathrm{g} \mathrm{m}^{-3}$ ) incorporates both the variance of the prediction and its bias.

\subsection{Mineral dust components}

The model reproduces the mineral dust cations $\left(\mathrm{K}^{+}, \mathrm{Mg}^{2+}\right.$, $\mathrm{Ca}^{2+}$ ) measured by the EMEP network remarkably well (RMSE $\sim 0.1 \mu \mathrm{g} \mathrm{m}^{-3}$ ), indicating that their representation over the Sahara (e.g., mineral dust chemical composition and emission fluxes) proposed by this study is of the correct magnitude and is suitable to be used to estimate their effect on nitrate aerosol formation over Europe. Similarly, the model performs well in reproducing the mineral dust cations over North America (Table 3), indicating that the emissions from the deserts of the western USA suggested by this study are close to reality. The concentrations of $\mathrm{K}^{+}$and $\mathrm{Mg}^{+2}$ are reproduced well by the model $\left(\mathrm{RMSE}=0.05 \mu \mathrm{g} \mathrm{m}^{-3}\right.$ ), while $\mathrm{Ca}^{+2}$ is underestimated with $\mathrm{NMB}=-0.17$. In contrast to Europe and North America, mineral cations are underpredicted by the model over eastern Asia, especially calcium $(\mathrm{NMB}=-0.7)$, indicating that the central Asian deserts could have a larger impact than assumed in this study. 
Table 3. Statistical evaluation of EMAC-simulated aerosol concentrations against monthly average observations from North America during 2005-2008.

\begin{tabular}{lrrrrrrrr}
\hline $\begin{array}{l}\text { CASTNET network } \\
\text { Metric }\end{array}$ & $\mathrm{NO}_{3}^{-}$ & $\mathrm{Na}^{+}$ & $\mathrm{Ca}^{2+}$ & $\mathrm{K}^{+}$ & $\mathrm{Mg}^{2+}$ & $\mathrm{NH}_{4}^{+}$ & $\mathrm{Cl}^{-}$ & $\mathrm{SO}_{4}^{2-}$ \\
\hline Observed $\left(\mu \mathrm{g} \mathrm{m}^{-3}\right)$ & 0.86 & 0.09 & 0.29 & 0.06 & 0.04 & 1.04 & 0.05 & 2.81 \\
Calculated $\left(\mu \mathrm{g} \mathrm{m}^{-3}\right)$ & 0.82 & 0.27 & 0.12 & 0.05 & 0.06 & 0.85 & 0.37 & 2.11 \\
MAGE $\left(\mu \mathrm{g} \mathrm{m}^{-3}\right)$ & 0.8 & 0.19 & 0.22 & 0.03 & 0.04 & 0.45 & 0.34 & 1.05 \\
$\mathrm{MB}\left(\mu \mathrm{g} \mathrm{m}^{-3}\right)$ & -0.04 & 0.18 & -0.17 & -0.01 & 0.02 & -0.19 & 0.32 & -0.71 \\
$\mathrm{NME}$ & 0.92 & 2.09 & 0.75 & 0.53 & 0.92 & 0.43 & 6.36 & 0.37 \\
$\mathrm{NMB}$ & -0.05 & 1.94 & -0.58 & -0.13 & 0.4 & -0.18 & 6.13 & -0.25 \\
RMSE $\left(\mu \mathrm{g} \mathrm{m}^{-3}\right)$ & 1.19 & 0.24 & 0.38 & 0.05 & 0.05 & 0.06 & 0.5 & 1.5 \\
Number of comparisons & 1523 & 1523 & 1523 & 1522 & 1523 & 1523 & 1523 & 1523 \\
\hline
\end{tabular}

Table 4. Statistical evaluation of EMAC-simulated aerosol concentrations against monthly average observations from East Asia during 2005-2008.

\begin{tabular}{lrrrrrrrr}
\hline $\begin{array}{l}\text { EANET network } \\
\text { Metric }\end{array}$ & $\mathrm{NO}_{3}^{-}$ & $\mathrm{Na}^{+}$ & $\mathrm{Ca}^{++}$ & $\mathrm{K}^{+}$ & $\mathrm{Mg}^{++}$ & $\mathrm{NH}_{4}^{+}$ & $\mathrm{Cl}^{-}$ & $\mathrm{SO}_{4}^{--}$ \\
\hline Observed $\left(\mu \mathrm{g} \mathrm{m}^{-3}\right)$ & 1.16 & 1 & 0.74 & 0.36 & 0.16 & 1.1 & 1.39 & 4.44 \\
Calculated $\left(\mu \mathrm{g} \mathrm{m}^{-3}\right)$ & 0.47 & 0.58 & 0.21 & 0.09 & 0.11 & 0.44 & 1.05 & 1.46 \\
MAGE $\left(\mu \mathrm{g} \mathrm{m}^{-3}\right)$ & 0.94 & 0.79 & 0.7 & 0.29 & 0.14 & 0.77 & 1.43 & 3.18 \\
$\mathrm{MB}\left(\mu \mathrm{g} \mathrm{m}^{-3}\right)$ & -0.69 & -0.42 & -0.53 & -0.27 & -0.05 & -0.66 & -0.34 & -2.98 \\
$\mathrm{NME}$ & 0.82 & 0.79 & 0.95 & 0.83 & 0.83 & 0.7 & 1.03 & 0.72 \\
$\mathrm{NMB}$ & -0.59 & -0.4 & -0.7 & -0.75 & -0.27 & -0.59 & -0.21 & -0.67 \\
RMSE $\left(\mu \mathrm{g} \mathrm{m}^{-3}\right)$ & 2.24 & 1.53 & 1.83 & 0.7 & 0.22 & 1.54 & 2.59 & 5.02 \\
Number of comparisons & 1279 & 1274 & 1528 & 1523 & 1414 & 1277 & 1140 & 1294 \\
\hline
\end{tabular}

\subsection{Nitrate}

EMAC systematically overpredicts nitrate concentrations compared to measurements from the EMEP network $\left(\mathrm{MB}=0.88 \mu \mathrm{g} \mathrm{m}^{-3}\right)$. This discrepancy is not the result of errors in the partitioning of the available nitric acid, since EMAC significantly overestimates the total nitric acid concentrations $\left(\mathrm{MB}=2.29 \mu \mathrm{g} \mathrm{m}^{-3}\right)$. However, considering that routine nitrate filter-based measurements could be lowbiased due to the partial evaporation of nitrate from the Teflon filters (Ames and Malm, 2001; Hering and Cass, 1999), notably at high temperatures in summer, some of this discrepancy can be attributed to the measurements as well. The model has the best overall performance statistically when compared against measurements from the CASTNET network, in comparison to the model performance over the EMEP and EANET networks. This is quite encouraging given that the CASTNET sites are located in rural areas and are not affected directly by urban sources which cannot be adequately captured by EMAC due to its coarse spatial resolution. Nitrate is unbiased when compared to the CASTNET network $\left(\mathrm{MB}=-0.04 \mu \mathrm{g} \mathrm{m}^{-3}\right.$ ) indicating that the model is successful in reproducing the relatively low nitrate levels over the continental USA $\left(\sim 0.8 \mu \mathrm{g} \mathrm{m}^{-3}\right)$. However, the NME is equal to 0.92 which indicates a high scatter.
Considering that filter-based nitrate measurements are uncertain by roughly $\pm 0.5 \mathrm{\mu g} \mathrm{m}^{-3}$ (Solomon et al., 2001; Karydis et al., 2007), this discrepancy at low nitrate concentrations could also be partially related to the measurements. Furthermore, there is little day-to-day variation of the emissions in the model and this simplification probably adds to the scatter as well. The model underpredicts all aerosol components over eastern Asia, including nitrate, since it cannot capture the high concentrations observed over the urban centers of the Asian megacities (i.e., Beijing) due to its limited spatial resolution. Further, we apply emissions for 2005, which are probably low-biased for the following years considering the rapid growth of emissions in Asia. The underestimation of mineral cation emissions is also responsible for the underprediction of nitrate aerosol concentrations $\left(\mathrm{MB}=-0.69 \mu \mathrm{g} \mathrm{m}^{-3}\right)$ over eastern Asia. Therefore, the impact of mineral dust on nitrate aerosol formation over Asia calculated by this study is probably underestimated as well.

\subsection{Rest of inorganic aerosol components}

Over Europe, ammonium is slightly overpredicted $(\mathrm{NMB}=0.33)$ at least partly driven by the overprediction of sulfate and nitrate concentrations (Table 2). On the other hand, sodium and chloride are slightly underpredicted 
by the model $\left(\mathrm{MB}=-0.26 \mu \mathrm{g} \mathrm{m}^{-3}\right.$ and $-0.31 \mu \mathrm{g} \mathrm{m}^{-3}$, respectively), indicating a possible underestimation of sea salt emissions or a removal during transport that is too rapid. Over North America, sulfate and ammonium are underestimated by the model; however, the model performance is substantially improved when looking at other components (Table 3). Observed chloride concentrations are very low $\left(0.05 \mu \mathrm{g} \mathrm{m}^{-3}\right)$. While the simulated concentrations are also low, they are systematically higher than the measurements with an $\mathrm{MB}$ of $0.32 \mu \mathrm{g} \mathrm{m}^{-3}$. Over eastern Asia, sulfate is significantly underpredicted $(\mathrm{NMB}=-0.67)$ since the observed concentrations are systematically high (i.e., $60 \mu \mathrm{g} \mathrm{m}^{-3}$ over Hanoi during April 2007), not captured by the model. This results in an underprediction of ammonium concentrations as well $(\mathrm{NMB}=-0.59)$ since ammonium is mostly sensitive to sulfate concentrations. Chloride concentrations are slightly underpredicted by the model $(\mathrm{NMB}=-0.21$ ); however, the significant error $(\mathrm{NME}=1.03)$ indicates a high scatter.

\section{Model results}

\subsection{Mineral dust}

The modeled global multi-year average surface concentration of mineral dust is $24 \mu \mathrm{g} \mathrm{m}^{-3}$ (Fig. 2a). High concentrations of mineral dust are calculated over the deserts (e.g., $1600 \mu \mathrm{g} \mathrm{m}^{-3}$ over the Bodélé Depression, Sahara) and partly transported over very long distances (Fig. 2a). Dust particles originating from the Sahara can travel across the tropical Atlantic Ocean $\left(10-90 \mu \mathrm{g} \mathrm{m}^{-3}\right)$ and across the Mediterranean, affecting air quality in southern Europe (10$\left.60 \mu \mathrm{g} \mathrm{m}^{-3}\right)$. The northwestern USA is mostly affected by dust originating from the Great Basin, Mojave, and Sonoran deserts $\left(60-440 \mu \mathrm{g} \mathrm{m}^{-3}\right)$. Dust concentrations can also be enhanced over the Pacific Ocean off the coast of California $\left(2-15 \mu \mathrm{g} \mathrm{m}^{-3}\right)$. Dust from the Arabian $\left(90-3000 \mu \mathrm{g} \mathrm{m}^{-3}\right)$, Thar $\left(150-5000 \mu \mathrm{g} \mathrm{m}^{-3}\right)$, Taklimakan $\left(250-9000 \mu \mathrm{g} \mathrm{m}^{-3}\right)$, and Gobi $\left(70-1900 \mu \mathrm{g} \mathrm{m}^{-3}\right)$ deserts significantly affects air quality over the Middle East and Asia $\left(250 \mu \mathrm{g} \mathrm{m}^{-3}\right.$ on average). Mineral dust from the Thar and Arabian deserts affects the atmosphere over the Arabian Sea $\left(15-100 \mu \mathrm{g} \mathrm{m}^{-3}\right)$. Over the Yellow Sea and North Pacific Ocean, dust concentrations are predicted to be $2-30 \mu \mathrm{g} \mathrm{m}^{-3}$ due to the long-range transport of dust from the Taklimakan and Gobi deserts. Dustaffected regions in the Southern Hemisphere are found in South America, e.g., from the Atacama $\left(600-5000 \mu \mathrm{g} \mathrm{m}^{-3}\right)$ and Patagonian (250-2000 $\mu \mathrm{g} \mathrm{m}^{-3}$ ) deserts; Australia, e.g., from the Great Sandy and Simpson deserts (20-200 $\mu \mathrm{g} \mathrm{m}^{-3}$ ), and South Africa, e.g., from the Kalahari (100-700 $\mu \mathrm{g} \mathrm{m}^{-3}$ ) and Namibian deserts $\left(100-2700 \mu \mathrm{g} \mathrm{m}^{-3}\right)$. Mineral dust from the Patagonian desert is efficiently transported over the South Atlantic Ocean $\left(15-150 \mu \mathrm{g} \mathrm{m}^{-3}\right)$ due to winds associated with the Antarctic circumpolar vortex that flow eastward around Antarctica. The dust emissions generated in South America are higher than what is stated in the literature and from satellite images (i.e., MODIS). As discussed in Astitha et al. (2012), the main reasons behind this overprediction are the coarse model resolution in a region with pronounced topography, which is a consequence of applying a consistent emission scheme throughout the globe without the use of regionally tuned emission fluxes.

\subsubsection{Calcium}

The global multi-year average surface concentration of calcium is $3.2 \mu \mathrm{g} \mathrm{m}^{-3}$ (Fig. 2b). The highest calcium concentrations are predicted over the Taklimakan Desert (50$1500 \mu \mathrm{g} \mathrm{m}^{-3}$ ), where mineral dust emissions are extremely high and rich in calcium (12\%). Dust particles originating from the Namibian Desert are also rich in calcium $(12 \%)$, which results in high aerosol concentrations over the area $\left(50-800 \mu \mathrm{g} \mathrm{m}^{-3}\right)$. Over the dust belt (e.g., Sahara, Thar, Gobi) the percentage of calcium in mineral aerosols is around $7 \%$ and the predicted aerosol concentration is 10 $200 \mu \mathrm{g} \mathrm{m}^{-3}$. In the rest of the world (e.g., the Americas and Australia) the percentage of calcium in mineral aerosols is less than $5 \%$ and the concentration is less than $60 \mu \mathrm{g} \mathrm{m}^{-3}$, with the lowest values over Australia $\left(0.5-2 \mu \mathrm{g} \mathrm{m}^{-3}\right)$. In these areas, high calcium concentrations are calculated only over the Atacama Desert (20-200 $\left.\mu \mathrm{g} \mathrm{m}^{-3}\right)$ due to very high dust aerosol emissions.

\subsubsection{Potassium}

The global multi-year average surface concentration of potassium is $1.4 \mu \mathrm{g} \mathrm{m}^{-3}$ (Fig. 2c). The spatial distribution of potassium is similar to that of calcium due to their common origin; however, its magnitude is lower since the fraction of potassium in mineral dust is lower than that of calcium over all deserts (Table 1). The highest potassium concentrations are predicted over the Taklimakan $\left(20-600 \mu \mathrm{g} \mathrm{m}^{-3}\right)$ and Namibian $\left(20-350 \mu \mathrm{g} \mathrm{m}^{-3}\right)$ deserts where mineral dust emissions are highest and consist of $5 \%$ potassium. Over the Sahara and Thar deserts, where mineral dust is also rich in potassium $(\sim 3 \%)$, concentrations are predicted to be $2-$ $140 \mu \mathrm{g} \mathrm{m}^{-3}$. Over other deserts, the percentage of potassium in mineral aerosols is low (0.1-2\%) and the concentration is less than $50 \mu \mathrm{g} \mathrm{m}^{-3}$, with the lowest values predicted over Australia $\left(0.5 \mu \mathrm{g} \mathrm{m}^{-3}\right)$.

\subsubsection{Magnesium}

Magnesium is considered the least important chemically active constituent of mineral dust (Table 1). The global multi-year average surface concentration of magnesium is $1.7 \mu \mathrm{g} \mathrm{m}^{-3}$ (Fig. 2d). The highest magnesium concentrations are predicted over the Namibian Desert $\left(40-630 \mu \mathrm{g} \mathrm{m}^{-3}\right.$ ) where mineral dust is rich in magnesium $(9 \%)$. High magnesium concentrations also occur over the Taklimakan Desert 
(a) Dust

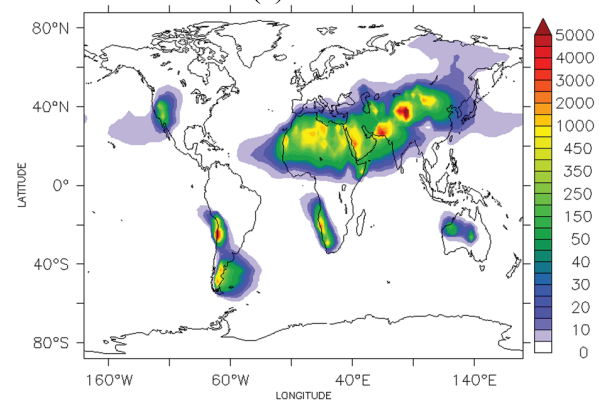

(b) Calcium

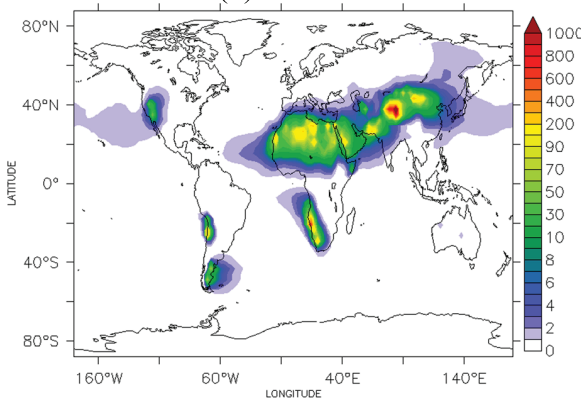

(d) Magnesium

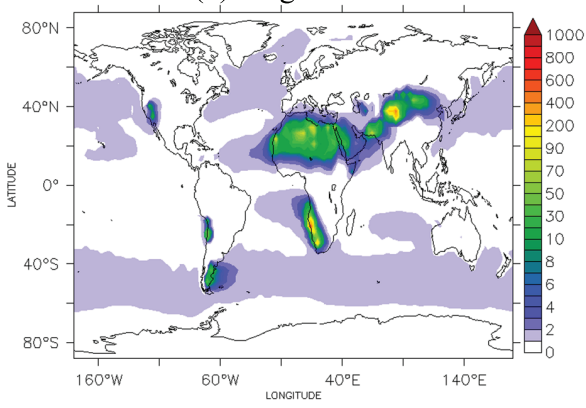

(c) Potassium

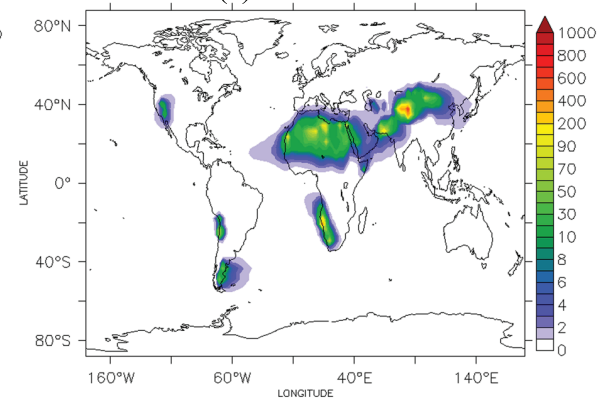

(e) Sodium

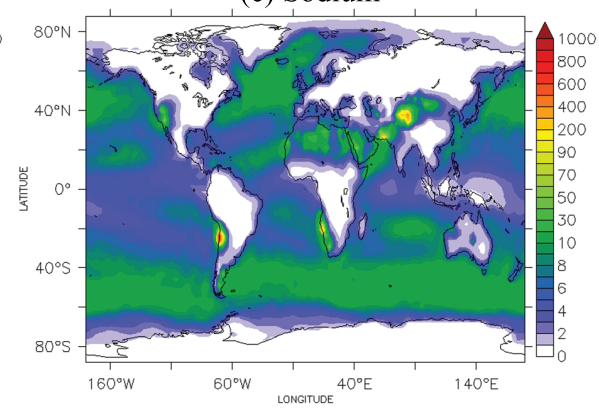

Figure 2. Predicted average near-surface concentrations (in $\mu \mathrm{g} \mathrm{m}^{-3}$ ) of (a) inert dust, (b) calcium, (c) potassium, (d) magnesium and (e) sodium during the years 2005-2008.

$\left(10-400 \mu \mathrm{g} \mathrm{m}^{-3}\right)$ due to the high dust emissions over the area. Over the Sahara, magnesium concentrations are 2$90 \mathrm{\mu g} \mathrm{m}^{-3}$, while over other desert areas of the world, levels are lower (mostly below $60 \mu \mathrm{g} \mathrm{m}^{-3}$ ) since its fraction in the dust aerosols is less than $2 \%$. In contrast to calcium and potassium, magnesium constitutes a nontrivial part of sea spray emissions $(3.7 \%)$ which results in $1-2 \mu \mathrm{g} \mathrm{m}^{-3}$ of magnesium over the southern oceans (South Atlantic, Pacific, and Indian oceans) and the North Atlantic and Pacific oceans.

\subsubsection{Sodium}

The global multi-year average surface concentration of sodium is $5.4 \mathrm{\mu g} \mathrm{m}^{-3}$ (Fig. 2e). Sodium has high concentrations both over the deserts, following the spatial distribution of the rest chemically active dust components, and over the oceans, since it represents an important constituent of sea salt $(30.6 \%)$. The highest sodium concentrations are predicted over the Atacama Desert (100-700 $\mu \mathrm{g} \mathrm{m}^{-3}$ ) due to high mineral dust percentages of sodium $(7 \%)$. High sodium concentrations also occur over the Taklimakan $\left(10-400 \mu \mathrm{g} \mathrm{m}^{-3}\right)$, Namibian $\left(10-200 \mu \mathrm{g} \mathrm{m}^{-3}\right)$, and Thar $(5-$ $100 \mu \mathrm{g} \mathrm{m}^{-3}$ ) deserts. Over the oceans, sodium concentrations are $2-15 \mu \mathrm{g} \mathrm{m}^{-3}$, with the highest concentrations over the southern oceans.

\subsection{Nitrate}

The global multi-year average surface concentration of aerosol nitrate is $0.34 \mu \mathrm{g} \mathrm{m}^{-3}$. The predicted total (gaseous nitric acid and aerosol) nitrate is $2-3 \mu \mathrm{g} \mathrm{m}^{-3}$ over the continents and can exceed $5 \mu \mathrm{g} \mathrm{m}^{-3}$ in the industrialized areas of Europe, central and eastern Asia, North America, as well as over biomass burning regions in the tropics (Fig. 3a). The highest values are found in the vicinity of Beijing in northeastern China $\left(\sim 10 \mu \mathrm{g} \mathrm{m}^{-3}\right)$. Total marine nitrate concen- 
(a) Total nitrate (gas plus aerosol)

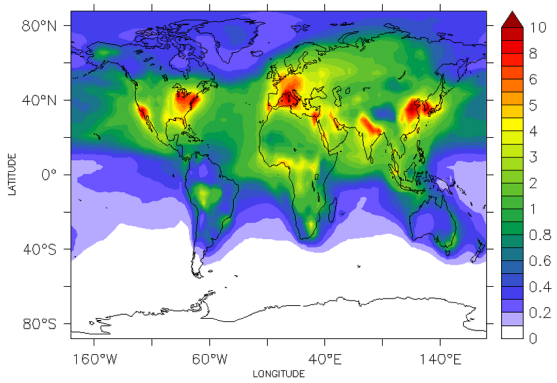

(b) Aerosol nitrate

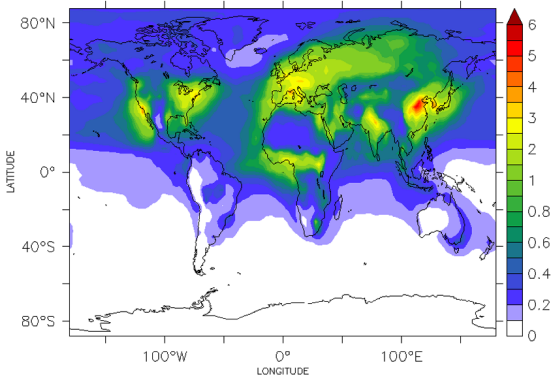

(c) Fraction of fine-mode aerosol nitrate

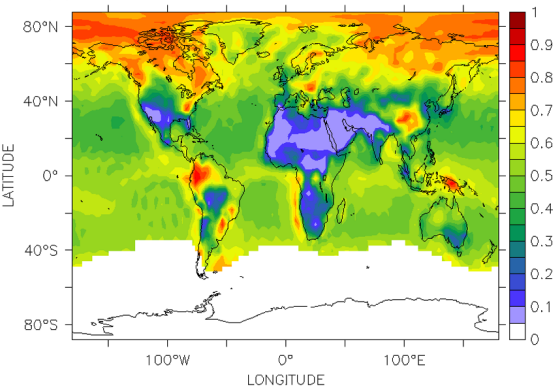

Figure 3. Predicted average near-surface concentrations (in $\mu \mathrm{g} \mathrm{m}^{-3}$ ) of (a) total nitrate (sum of gas and aerosol phases), (b) aerosol nitrate, and (c) fraction of fine-mode aerosol nitrate to total aerosol nitrate during the years 2005-2008.

trations are $1-2 \mu \mathrm{g} \mathrm{m}^{-3}$ on average nearly everywhere over the North Atlantic and Pacific oceans, i.e., significantly enhanced compared to the oceans of the Southern Hemisphere. Fine aerosol nitrate is calculated to be higher in densely populated areas over Europe, China, and the eastern USA (1$3 \mu \mathrm{g} \mathrm{m}^{-3}$ ), mostly produced from local photochemistry, and decreases with distance from the urban source areas due to dilution and deposition, remaining at low levels in surrounding areas (lower than $0.5 \mu \mathrm{g} \mathrm{m}^{-3}$ ) (Fig. $3 \mathrm{~b}$ and c). Simulated coarse aerosol nitrate is found to be enhanced over southern Europe, the Arabian peninsula, central and eastern Asia, and southwestern USA $\left(1-4 \mu \mathrm{g} \mathrm{m}^{-3}\right)$, where $\mathrm{HNO}_{3}$ from anthropogenic sources interacts with mineral dust from the surrounding deserts and thus largely condenses onto the coarse mode (Fig. 3b and c). Over these areas, where sulfuric acid is high, the bulk equilibrium assumption can result in the underprediction of coarse nitrate since it allows for instantaneous condensation of all the available sulfuric acid in the aerosol phase, leaving more nitrate in the gaseous state. On the other hand, a dynamic solution of the mass transfer equations will result in a gradual condensation of gases and will leave more particle surface available for nitrate condensation. Coarsemode aerosol nitrate is also high over central Africa where $\mathrm{HNO}_{3}$ from biomass burning is adsorbed on the surface of coarse soil particles from the Sahara. Taking into account that sulfuric acid concentrations over central Africa are low, nitric acid (which is in excess) is practically the only available acid in the atmosphere to react with the mineral cations.
In this case, the assumption of thermodynamic equilibrium in the coarse mode may result in an overprediction of coarse aerosol nitrate. Assuming bulk equilibrium only for the fine aerosols and a dynamical approach for coarse particles could eliminate a possible bias (Capaldo et al., 2000; Karydis et al., 2010). However, the additional calculations required for the dynamic solution of the mass transfer equations adds significantly to the computational overhead of the model. In this study, the kinetic limitations of the gas/aerosol partitioning in the coarse mode are considered by using only the fraction of the gas that can kinetically condense within the time step of the model in the equilibrium calculations.

\subsection{Rest inorganic aerosol components}

\subsubsection{Sulfate}

The global multi-year average surface concentration of aerosol sulfate is $1.8 \mu \mathrm{g} \mathrm{m}^{-3}$ (Fig. 4a). The highest aerosol sulfate concentrations are predicted over the industrialized areas of East Asia (3-10 $\left.\mu \mathrm{g} \mathrm{m}^{-3}\right)$, Europe (3-8 $\left.\mu \mathrm{g} \mathrm{m}^{-3}\right)$, India $\left(2-6 \mu \mathrm{g} \mathrm{m}^{-3}\right)$, and the eastern USA $\left(2-5 \mu \mathrm{g} \mathrm{m}^{-3}\right)$, mostly in the fine mode. Sulfate concentrations can also exceed $4 \mu \mathrm{g} \mathrm{m}^{-3}$ over the Mediterranean as a result of transport of sulfur species from Europe. Concentrations over remote continental areas are $1-2 \mu \mathrm{g} \mathrm{m}^{-3}$ nearly everywhere in the Northern Hemisphere. Over the oceans, aerosol sulfate is mostly in the coarse mode, associated with sea spray emissions, leading to concentrations around $3 \mu \mathrm{g} \mathrm{m}^{-3}$. The high- 
(a) Sulfate

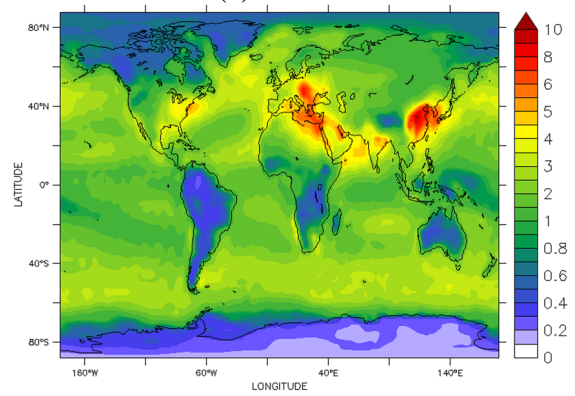

(b) Ammonium

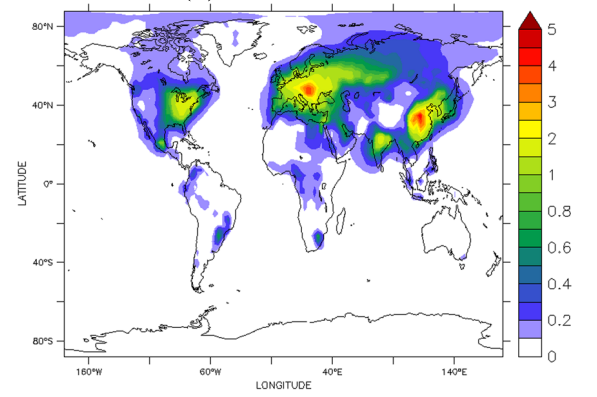

(c) Chloride

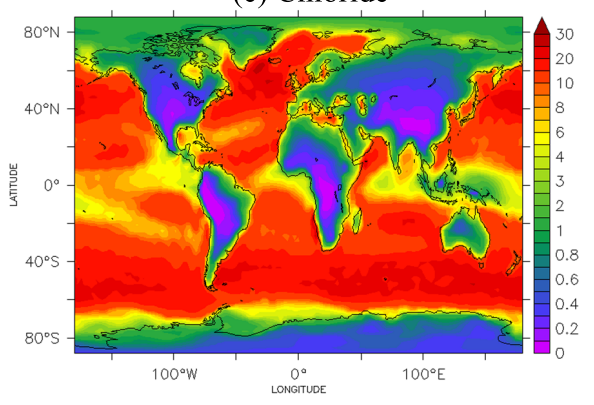

Figure 4. Predicted average near-surface concentrations (in $\mu \mathrm{g} \mathrm{m}^{-3}$ ) of (a) sulfate, (b) ammonium, and (c) chloride during the years $2005-$ 2008 .

est concentrations $\left(4-5 \mu \mathrm{g} \mathrm{m}^{-3}\right)$ are calculated around the Arabian peninsula (i.e., over the eastern Mediterranean and Persian Gulf), off the northeastern American and Asian coasts, and over the North Atlantic Ocean. Relatively high concentrations $\left(3-4 \mu \mathrm{g} \mathrm{m}^{-3}\right.$ ) are also found over the southern oceans due to high DMS emissions. The lowest marine aerosol sulfate concentrations, less than $1 \mu \mathrm{g} \mathrm{m}^{-3}$, occur over the remote tropical Pacific and Indian oceans.

\subsubsection{Ammonium}

The global multi-year average surface concentration of aerosol ammonium is $1.8 \mu \mathrm{g} \mathrm{m}^{-3}$ (Fig. 4b). Ammonium calculations are very sensitive to the ammonia emissions and the calculated sulfate and nitrate concentrations. Therefore, ammonium follows the spatial distribution of sulfate and nitrate with high concentrations over East Asia $\left(3-10 \mu \mathrm{g} \mathrm{m}^{-3}\right)$, Europe $\left(3-8 \mu \mathrm{g} \mathrm{m}^{-3}\right)$, India $\left(2-6 \mu \mathrm{g} \mathrm{m}^{-3}\right)$, and eastern USA $\left(2-5 \mu \mathrm{g} \mathrm{m}^{-3}\right)$, mostly in the form of ammonium sulfate and ammonium bisulfate and secondarily in the form of ammonium nitrate. Ammonium is also high over the biomass burning regions in the tropics, mostly in the form of ammonium nitrate $\left(3-10 \mu \mathrm{g} \mathrm{m}^{-3}\right)$. Over the oceans, ammonium concentrations are negligible.

\subsubsection{Chloride}

The global multi-year average surface concentration of aerosol chloride is $7.8 \mu \mathrm{g} \mathrm{m}^{-3}$ (Fig. 4c). The highest concentrations are predicted over the southern oceans and the
North Atlantic Ocean (20-25 $\left.\mu \mathrm{g} \mathrm{m}^{3}\right)$ due to large sea spray emissions caused by the strong winds in the storm tracks associated with the synoptic-scale vortices that circumvent the poles. Over the equatorial regions the chloride concentrations are $5-10 \mu \mathrm{g} \mathrm{m}^{-3}$. Over the continents, chloride concentrations are high close to the coasts $\left(2-7 \mu \mathrm{g} \mathrm{m}^{3}\right)$ and decrease rapidly with distance over land due to deposition processes.

\section{Mineral dust effect on inorganic aerosol}

To estimate the effects of mineral dust on the inorganic aerosol concentration, on the phase partitioning of nitrate, and on the size distribution of nitrate aerosols, a sensitivity run was conducted, switching off the dust-aerosol chemistry. Therefore, in this sensitivity simulation mineral dust is considered to be a bulk species without chemical identity, and cations $\left(\mathrm{Ca}^{2+}, \mathrm{Mg}^{2+}, \mathrm{K}^{+}, \mathrm{Na}^{+}\right)$exist only as part of the sea salt aerosols. This is a dust configuration that is common in atmospheric chemistry transport and climate calculations.

\subsection{Effects on inorganic aerosol concentrations}

\subsubsection{Effects on nitrate aerosols}

The absolute and fractional changes of aerosol nitrate concentration at the surface between the base case and the sensitivity simulation are depicted in Fig. 5. Positive changes correspond to higher concentrations in the base case. The predicted aerosol nitrate is higher in the base case simulation 
(a) Absolute change of aerosol nitrate

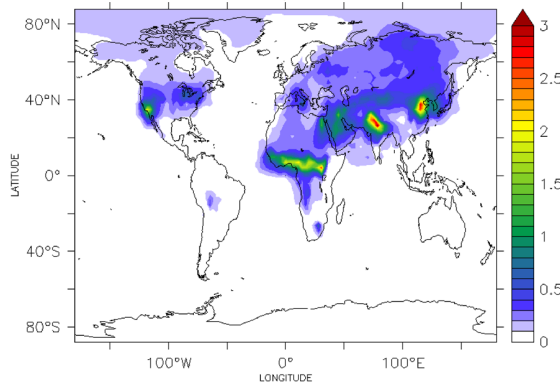

(b) Fractional change of aerosol nitrate

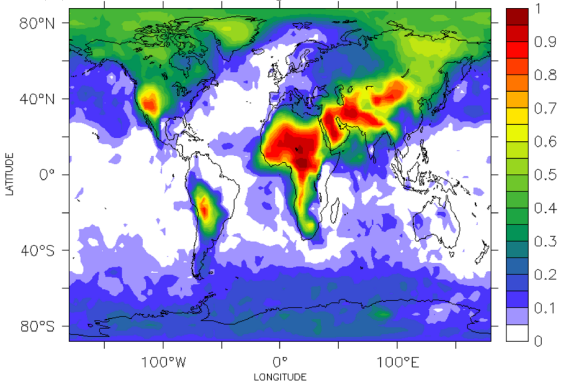

Figure 5. (a) Absolute (in $\mu \mathrm{g} \mathrm{m}^{-3}$ ) and (b) fractional change of the predicted average near-surface aerosol nitrate by ignoring the effect of the reactive dust components on its formation, during the years 2005-2008. A positive change corresponds to a decrease after assuming chemically inert dust.

(up to $3 \mu \mathrm{g} \mathrm{m}^{-3}$ ) due to the formation of salts with mineral components $\left(\mathrm{NaNO}_{3}, \mathrm{Ca}\left(\mathrm{NO}_{3}\right)_{2}, \mathrm{KNO}_{3}, \mathrm{Mg}\left(\mathrm{NO}_{3}\right)_{2}\right)$. This does not take place in the sensitivity simulation where mineral dust is assumed to be chemically inert, and nitric acid remains in the gas phase. The predicted fractional change of nitrate aerosol concentration due to the interaction with mineral dust cations is up to $100 \%$ over the main deserts with the highest values calculated over the Saharan, Arabian, and Indian deserts. The relatively lowest fractional changes are calculated over the deserts of the Southern Hemisphere (i.e., Patagonia, Australia). The contribution of mineral dust to aerosol nitrate is not only important over areas with high dust concentrations but also downwind of the sources. For instance, across southern Europe the aerosol nitrate concentration increases due to the dust aerosol chemistry treatment by $0.5 \mu \mathrm{g} \mathrm{m}^{-3}$, over western and eastern USA by 2 and $0.5 \mu \mathrm{g} \mathrm{m}^{-3}$, respectively, over eastern China and northern India by $0.5 \mu \mathrm{g} \mathrm{m}^{-3}$, and over central Africa by $2 \mu \mathrm{g} \mathrm{m}^{-3}$. Overall, the total predicted domain average nitrate aerosol concentration at the surface increases by $36 \%$ when considering the interactions of nitrate with mineral dust cations.

The tropospheric burdens of nitrate aerosols calculated in the base case and the sensitivity simulations are listed in Table 5. The nitrate aerosol tropospheric burden increases substantially by $0.2 \mathrm{Tg}$, i.e., $44 \%$, when considering the dust aerosol chemistry. Moreover, the tropospheric burden of total nitrate (gaseous $\mathrm{HNO}_{3}$ and aerosol nitrate) is $0.07 \mathrm{Tg}(3 \%)$ lower in the base case simulation even though the $\mathrm{NO}_{x}$ emissions remain unchanged in the sensitivity test. This difference is due to the more efficient removal of total nitrate since the base case predicts a higher fraction of total nitrate in the aerosol phase compared to the sensitivity simulation. Nitrate aerosols are removed more efficiently through both dry and wet deposition compared to the gas-phase $\mathrm{HNO}_{3}$, especially the nitrate in coarse-mode particles that are additionally removed by sedimentation.

\subsubsection{Effects on the rest inorganic aerosol components}

The tropospheric burdens of the main inorganic aerosols calculated in the base case and the sensitivity simulations are listed in Table 5. Chloride anions are associated with the non-volatile mineral cations, which results in an increase of the aerosol chloride tropospheric burden by $0.3 \mathrm{Tg}(9 \%)$. The tropospheric burden of ammonium decreases by $0.12 \mathrm{Tg}$ (41\%) due to dust aerosol chemistry, even though it is not associated directly with the alkaline mineral components. This decrease can be attributed to the reduction of available nitric acid in the atmosphere due to the presence of the mineral cations, which leads to a decrease of ammonium nitrate production. Sulfate aerosol increases by $0.13 \mathrm{Tg}(7 \%)$ by taking the mineral dust components into account. Sulfate is a nonvolatile aerosol compound and exists in the particulate phase, even in the form of $\mathrm{H}_{2} \mathrm{SO}_{4}$, and therefore its phase partition is not affected by the presence of cations. However, $\mathrm{SO}_{4}^{2-}$ can be formed heterogeneously in fogs and clouds via the dissolution of gaseous $\mathrm{SO}_{2}$ and its oxidation by $\mathrm{H}_{2} \mathrm{O}_{2}$ or $\mathrm{O}_{3}$. The reaction of the dissolved $\mathrm{SO}_{2}$ with $\mathrm{O}_{3}$ can be very important at $\mathrm{pH}$ values greater than about 5 (Seinfeld and Pandis, 2006) and therefore, the in-cloud oxidation rate of $\mathrm{SO}_{2}$ can increase substantially in the presence of alkaline species such as the mineral cations that increase the $\mathrm{pH}$.

\subsection{Effects on phase partitioning of nitrate}

Figure 6 shows the fraction of total nitrate occurring in the aerosol phase $\left(\mathrm{NO}_{3}^{-}{ }_{\text {[Aerosol] }} /\left(\mathrm{NO}_{3}^{-}{ }_{\text {[Aerosol] }}+\mathrm{NO}_{3}^{-}{ }_{[\mathrm{Gas}]}\right)\right)$ calculated by the base case and the sensitivity simulations. In areas where the dust concentrations are high (over the deserts), nitric acid is associated with the non-volatile mineral cations $\left(\mathrm{Na}^{+}, \mathrm{Ca}^{2+}, \mathrm{K}^{+}, \mathrm{Mg}^{2+}\right)$ forming salts in order to maintain the charge balance in the aerosol phase. The fraction of nitrate in the aerosol phase varies between $10 \%$ over the Great Basin desert and $90 \%$ over the Gobi Desert where mineral dust is associated with nitric acid originating from the anthropogenic sources of eastern Asia. Over Africa, the 
Table 5. Calculated average tropospheric burden of inorganic components in the base case and the sensitivity simulations.

\begin{tabular}{|c|c|c|c|c|c|c|c|c|c|c|c|}
\hline \multirow[b]{2}{*}{ Simulation case } & \multicolumn{11}{|c|}{ Tropospheric burden of inorganic components (Tg) } \\
\hline & $\mathrm{NO}_{3}^{-}$ & $\mathrm{HNO}_{3}+\mathrm{NO}_{3}^{-}$ & Dust & $\mathrm{Na}^{+}$ & $\mathrm{Ca}^{++}$ & $\mathrm{K}^{+}$ & $\mathrm{Mg}^{++}$ & $\mathrm{NH}_{4}^{+}$ & $\mathrm{NH}_{3}+\mathrm{NH}_{4}^{+}$ & $\mathrm{Cl}^{-}$ & $\mathrm{SO}_{4}^{--}$ \\
\hline Base case* & 0.45 & 2.10 & 32.90 & 3.54 & 4.70 & 1.94 & 1.78 & 0.17 & 0.99 & 3.50 & 1.78 \\
\hline Homogeneous size distribution of dust & 0.41 & 2.12 & 20.56 & 2.87 & 2.83 & 1.22 & 1.22 & 0.18 & 0.97 & 3.45 & 1.80 \\
\hline Uniform chemical composition of dust & 0.38 & 2.14 & 35.34 & 2.95 & 1.88 & 1.20 & 0.92 & 0.19 & 0.96 & 3.43 & 1.77 \\
\hline $50 \%$ decrease in dust emissions & 0.41 & 2.13 & 18.61 & 2.90 & 2.69 & 1.13 & 1.12 & 0.19 & 0.97 & 3.46 & 1.82 \\
\hline
\end{tabular}

* The base case simulation takes into account the chemically active mineral dust components and it assumes that aerosols can form solids (stable state). The emission inventory used includes an explicit geographical representation of the emitted dust particle size distribution and chemical composition.

(a) Base case with chemically active dust

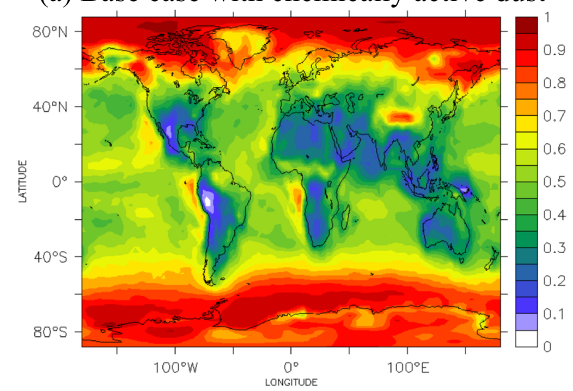

(b) Sensitivity case with chemically inert dust

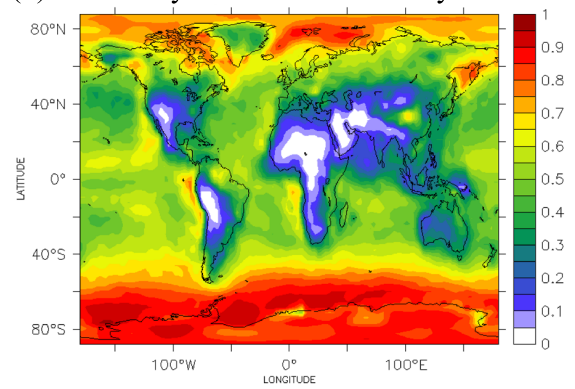

Figure 6. Predicted average near-surface fraction of total nitrate (gas plus aerosol) in the aerosol phase (a) by simulating the heterogeneous chemistry between dust and nitrate species (base case), and (b) by switching off dust chemistry (sensitivity case) during the years 2005-2008.

calculated nitrate aerosol fraction is $20-60 \%$, with the highest values predicted over the equatorial region, which is affected by high mineral dust concentrations from the Sahara and enhanced nitric acid concentrations from biomass burning in the Congo Basin. In the sensitivity simulation where dust reactive components are ignored, nitric acid largely remains in the gas phase in areas close to deserts.

\subsection{Effects on nitrate aerosol size distribution}

The fraction of aerosol nitrate in the coarse mode increases in the base case simulation since most of the mineral cations occur in the coarse mode. The model predicts that about $50 \%$ of the global mean total aerosol nitrate is in the coarse mode. In the sensitivity simulation in which mineral dust is assumed to be chemically inert, the corresponding fraction of coarsemode nitrate to total aerosol nitrate is $44 \%$. Over the deserts, the fraction of nitrate in the coarse mode is nearly $100 \%$ and declines with distance from the dust source regions. Since the model assumes that equilibrium is established separately for each mode, the presence of mineral cations in the coarse mode traps nitric acid vapor, thus lowering the nitric acid concentration in the gas phase. The fine aerosol then loses mass as evaporation is required to maintain equilibrium with the gas phase. As a result, the predicted fine aerosol nitrate may occasionally decrease in the presence of mineral dust. However, over areas where nitric acid is not the limiting reactant, nitrate increases in the fine mode, since a fraction of mineral dust exists in the fine mode as well. Overall, the domain average nitrate aerosol concentration at the surface increases by $21 \%$ in the fine mode and $53 \%$ in the coarse mode when considering the interactions of nitrate with mineral dust cations.

\section{Sensitivity tests}

We have conducted four additional sensitivity simulations to investigate whether the nitrate aerosol formation depends strongly on (i) the dust emission parameterization scheme, (ii) the chemical composition of the emitted dust aerosols, (iii) the strength of the dust aerosol emissions, and (iv) the aerosol state assumption. Figure 7 depicts the interannual absolute change of aerosol nitrate concentrations compared to the base case for each of the sensitivity simulations. A positive change corresponds to a decrease of the concentrations in the sensitivity simulations. The tropospheric burdens of the main inorganic aerosols from each of the sensitivity simulations are listed in Table 5.

\subsection{Sensitivity to the dust emission parameterization scheme}

The first sensitivity test utilizes a homogeneous global soil size distribution of dust particles, in contrast to the base case simulation that uses an explicit geographical representation. 
(a) Effect of the dust size distribution

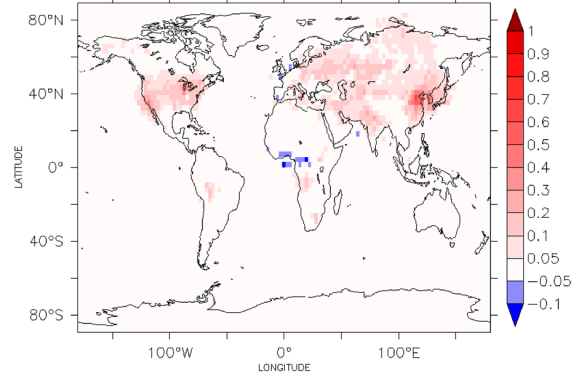

(c) Effect of the emitted dust aerosol load

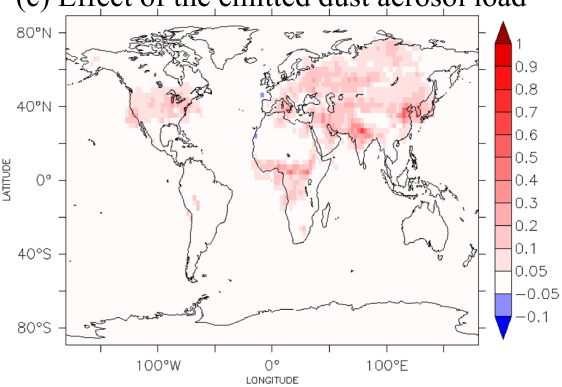

(b) Effect of the dust chemical composition

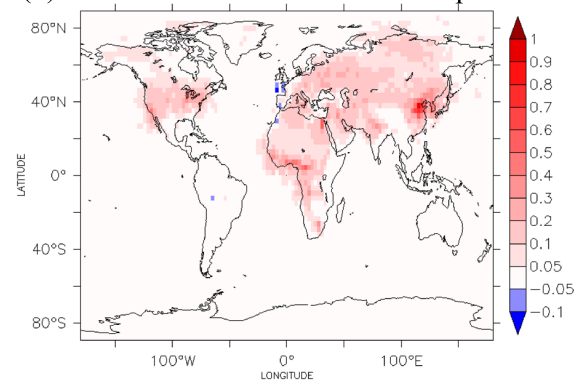

(d) Effect of the aerosol state assumption

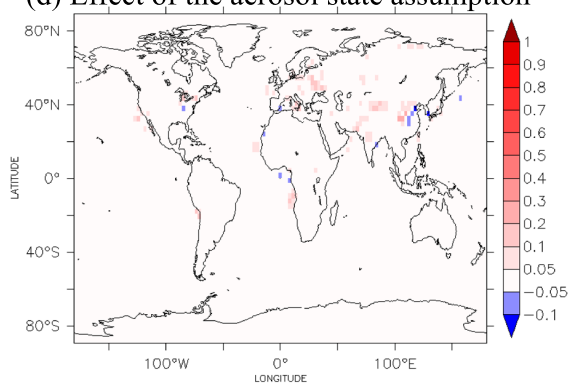

Figure 7. Absolute changes (in $\mu \mathrm{g} \mathrm{m}^{-3}$ ) of the predicted average near-surface aerosol nitrate after (a) using a dust emission parameterization scheme that utilizes a homogeneous global soil size distribution of dust particles, (b) assuming a global uniform chemical composition of mineral dust, (c) a 50\% reduction of mineral dust emissions, and (d) assuming a metastable state for aerosols, during the years 2005-2008. A positive change corresponds to a decrease in the sensitivity simulations.

Another difference between the two simulations is the emitted particle size distribution at the source; in the sensitivity case the D'Almeida (1987) "background" source modes are imposed uniformly in all grid cells, whereas the base case explicitly accounts for the soil characteristics in every grid cell. This influences the calculated threshold friction velocity, which triggers the dust mobilization and hence changes the dust aerosol emission fluxes. Consequently, the tropospheric burdens of mineral components calculated by the sensitivity case simulation differ substantially from the base case simulation (Table 5). The sensitivity simulation produces weaker emissions than the base case, mostly due to differences in the Asian and South American deserts (2 to 3 times lower emissions) and to a lesser extent in Saharan, Arabian, and Australian deserts (Astitha et al., 2012). The reduced emissions of mineral components in the sensitivity case simulation result in a decrease of the tropospheric nitrate burden by $9 \%$. The largest absolute decrease is calculated over northeastern China $\left(0.7 \mu \mathrm{g} \mathrm{m}^{-3}, 15 \%\right)$, which is affected by mineral dust emitted from the central Asian deserts. The highest fractional decrease is calculated over the eastern Amazon Basin $\left(0.4 \mu \mathrm{g} \mathrm{m}^{-3}\right.$ or $\left.40 \%\right)$ affected by dust from the Atacama Desert. The reduction of nitrate in the sensitivity simulation is also important over the western USA $\left(0.4 \mu \mathrm{g} \mathrm{m}^{-3}, 30 \%\right)$. On the other hand, over the Sahara the sensitivity case simulation predicts higher emissions of mineral components, which result in an increase of nitrate aerosol concentrations over the Congo Basin by $0.1 \mu \mathrm{g} \mathrm{m}{ }^{-3}$ $(10 \%)$.

\subsection{Sensitivity to the emitted dust aerosol composition}

The second sensitivity test assumes a globally uniform chemical composition of mineral dust in contrast to the base case simulation where the mineral dust composition depends on the soil characteristics of each desert. While the emitted total mineral dust aerosols remain the same between the two simulations, the different assumptions on the mineral dust chemical composition result in significant changes in the calculated tropospheric burden of the individual mineral dust components (Table 5). The fraction of the individual mineral components to total mineral dust assumed in the sensitivity simulation is lower in dust from most of the deserts compared to the base case (Table 1), which results in reduced emissions. This substantially affects not only the tropospheric burden of the mineral components $\left(\mathrm{Na}^{+}, \mathrm{Ca}^{+2}, \mathrm{~K}^{+}\right.$, and $\mathrm{Mg}^{+2}$, are reduced by $17,40,37$, and $48 \%$, respectively), but also the calculated tropospheric burden of nitrate aerosol, which decreases by $16 \%$ in the sensitivity simulation. The largest absolute decrease is calculated over northeastern China $\left(1 \mu \mathrm{g} \mathrm{m}^{-3}\right.$ or $\left.20 \%\right)$. The highest fractional decrease is calculated over the Congo Basin $\left(0.6 \mu \mathrm{g} \mathrm{m}^{-3}, 60 \%\right)$. Over the western USA nitrate decreases by $0.5 \mu \mathrm{g} \mathrm{m}{ }^{-3}$ or $\left.35 \%\right)$. On the other hand, nitrate aerosol 
concentrations are predicted to increase close to the Atacama Desert $\left(0.1 \mu \mathrm{g} \mathrm{m}^{-3}, 30 \%\right)$.

\subsection{Sensitivity to the emitted dust aerosol load}

The third sensitivity test assumes $50 \%$ lower emissions of mineral dust aerosol compared to the base case simulation, and is used to estimate the corresponding effect on the nitrate aerosol formation. Despite the drastic decrease of the atmospheric dust load (43\%), the tropospheric nitrate burden decreases by only $9 \%$ (Table 5). This is not unexpected since the thermodynamic interactions between nitrate and mineral components are mostly important over the deserts where nitric acid is the limiting reactant rather than the mineral dust. However, over areas that are located close to the main deserts and are at the same time rich in nitric acid, the impact of the dust emission reduction on the nitrate formation is substantial. For instance, nitrate aerosol concentrations decrease significantly over northeastern China $\left(0.7 \mu \mathrm{g} \mathrm{m}^{-3}\right.$, $15 \%)$, the Congo Basin $\left(0.5 \mu \mathrm{g} \mathrm{m}^{-3}, 40 \%\right)$, southern Europe $\left(0.3 \mu \mathrm{g} \mathrm{m}^{-3}, 15 \%\right)$, and the USA $\left(0.4 \mu \mathrm{g} \mathrm{m}^{-3}, 30 \%\right)$. The largest absolute decrease is calculated over northern India $\left(0.7 \mu \mathrm{g} \mathrm{m}^{-3}, 25 \%\right)$. The highest fractional decrease is calculated close to the Atacama Desert $\left(0.15 \mu \mathrm{g} \mathrm{m}^{-3}, 55 \%\right)$.

\subsection{Sensitivity to the aerosol state assumption}

The final sensitivity test assumes that the aerosol solution is aqueous even at very low RH (metastable assumption), and it is used to estimate the impact of the aerosol-phase state on the nitrate aerosol formation. The calculated tropospheric burden of nitrate aerosol decreases by only $2 \%$ in the sensitivity simulation. Ansari and Pandis (2000) suggested that the stable state (assumed in our base case simulation) results in higher concentrations of aerosol nitrate when the RH is very low $(<35 \%)$ and/or sulfate to nitrate molar ratios are low $(<0.25)$. This results in a decrease of the calculated nitrate aerosol concentrations close to deserts in the sensitivity simulation. The largest absolute decrease $\left(0.3 \mu \mathrm{g} \mathrm{m}^{-3}, 20 \%\right)$ is calculated around the central Asian deserts ( sulfate / nitrate $=0.3 ; \mathrm{RH}=20 \%$ ). The highest fractional decrease $\left(0.2 \mu \mathrm{g} \mathrm{m}^{-3}, 60 \%\right)$ is calculated close to the Atacama Desert (sulfate $/$ nitrate $=0.4 ; \mathrm{RH}=28 \%$ ). On the other hand, over areas where the sulfate to nitrate molar ratio is high (i.e., over eastern China, northeastern USA), or when the relative humidity is very high (i.e., over the Congo Basin), the metastable assumption results in higher nitrate aerosol concentrations. The largest absolute increase $\left(0.15 \mu \mathrm{g} \mathrm{m}^{-3}, 5 \%\right)$ is calculated over eastern China (sulfate $/$ nitrate $=0.9$; $\mathrm{RH}=86 \%$ ) and the highest fractional increase $\left(0.1 \mu \mathrm{g} \mathrm{m}^{-3}, 10 \%\right)$ over the Congo Basin (sulfate $/$ nitrate $=0.2 ; \mathrm{RH}=92 \%)$.

\section{Summary and conclusions}

This study assesses the effect of mineral dust particles on nitrate aerosol formation by using the thermodynamic equilibrium model ISORROPIA-II that takes the thermodynamics of the $\mathrm{K}^{+}, \mathrm{Ca}^{2+}, \mathrm{Mg}^{2+}, \mathrm{NH}_{4}^{+}, \mathrm{Na}^{+}, \mathrm{SO}_{4}^{2-}, \mathrm{NO}_{3}^{-}, \mathrm{Cl}^{-}$, and $\mathrm{H}_{2} \mathrm{O}$ components into account. The fine aerosol nitrate concentration is predicted to be higher over highly populated and industrialized areas (up to $3 \mu \mathrm{g} \mathrm{m}^{-3}$ ), while coarse aerosol nitrate is found to be higher over the deserts (up to $4 \mu \mathrm{g} \mathrm{m}^{-3}$ ).

The contribution of mineral dust to nitrate aerosol concentrations is significant in areas with high dust concentrations (near deserts) with impacts that can extend across southern Europe, western USA, and northeastern China. Over these areas, nitric acid is associated with non-volatile mineral cations $\left(\mathrm{Na}^{+}, \mathrm{Ca}^{2+}, \mathrm{K}^{+}, \mathrm{Mg}^{2+}\right)$ forming salts to maintain the charge balance in the aerosol phase. This is not reflected in the sensitivity simulation where dust reactive components are ignored and nitric acid remains solely in the gas phase in areas close to deserts. As a consequence, $36 \%$ higher global average nitrate aerosol concentrations are produced at the surface in the base case simulation, while the coarse- and fine-mode nitrate concentrations are higher by 53 and $21 \%$, respectively. The tropospheric burden of nitrate aerosol increases by $44 \%$ when considering dust aerosol chemistry. Given that all results from this study are reported as multi-annual averages, this contribution can be even more important during strong dust episodes.

Other inorganic aerosol components are affected by the presence of the reactive dust components as well. Chloride is directly associated with the mineral cations and its tropospheric burden increases by $9 \%$. The tropospheric burden of ammonium decreases by $41 \%$ due to the reduction of available nitric acid in the gas phase. The tropospheric burden of sulfate increases by $7 \%$ as the $\mathrm{pH}$-dependent in-cloud oxidation of $\mathrm{SO}_{2}$ by $\mathrm{O}_{3}$ increases due to the presence of alkaline mineral dust components.

Four additional simulation tests have been conducted to investigate the sensitivity of the results to the mineral dust emission parameterization scheme, the chemical composition of the emitted dust, the emitted dust aerosol load, and the aerosol state assumption. These simulations indicate that the calculated nitrate tropospheric burden is mostly sensitive to the chemical composition of mineral dust. By assuming a global uniform chemical composition of mineral dust, we find a reduction of $16 \%$ in the calculated tropospheric burden of nitrate aerosol. The results are moderately sensitive to the mineral dust aerosol load and the mineral dust emission scheme as the dust itself is often not the limiting factor (in both cases a $9 \%$ change in the nitrate aerosol tropospheric burden is calculated). The aerosol state assumption has a marginal effect on the calculated nitrate aerosol tropospheric burden ( $2 \%$ change); however, it can be important over deserts (stable state assumption predicts higher nitrate 
concentrations) and sulfate-rich areas (metastable state assumption predicts higher nitrate concentrations).

The relative importance of the examined parameters to the nitrate aerosol formation is not spatially uniform. The calculated nitrate aerosol concentrations are mostly sensitive to the mineral dust chemical composition over areas close to deserts that are rich in nitric acid (i.e., nitrate is reduced by $60 \%$ over the Congo Basin, $35 \%$ over the western USA, and $20 \%$ over the northeastern China). The aerosol state assumption is the most influential parameter in simulations of the nitrate aerosol formation over deserts at very low relative humidity (i.e., nitrate is reduced by $60 \%$ over the Atacama Desert where $\mathrm{RH}=28$ and $20 \%$ over the central Asian deserts where $\mathrm{RH}=20 \%$ ). Mineral dust emissions are the dominant factor for simulations of the nitrate aerosol formation over southern Europe (nitrate is reduced by $15 \%$ ) and northern India (nitrate is reduced by $25 \%$ ), while the size distribution of mineral dust is mostly important over the eastern Amazon Basin (nitrate is reduced by $40 \%$ ).

By using an explicit geographical representation of the emitted soil particle size distribution and chemical composition based on soil characteristics of each desert, we have quantified the impact of mineral dust on nitrate aerosol formation due to thermodynamical interactions (assuming equilibrium). Despite the sensitivities and associated uncertainties, we conclude that mineral dust aerosol chemistry is important for nitrate aerosol formation. Neglecting the thermodynamic interactions of nitrate with mineral cations may introduce significant biases in the global distribution of nitrate as well as other aerosol components, especially for coarsemode aerosols. Given that the coating of dust by hygroscopic salts affects its efficiency to grow by water uptake and act as cloud condensation nuclei, the ability to capture the complex interactions of mineral dust with the inorganic aerosol components is of prime importance for global and regional air quality and climate models. The role of mineral dust on cloud droplet formation will be investigated in a future study.

Acknowledgements. The research leading to these results has received funding from the European Research Council under the European Union's Seventh Framework Programme (FP7/2007-2013)/ERC grant agreement no. 226144. V. A. Karydis acknowledges support from a FP7 Marie Curie Career Integration Grant (project reference 618349). A. P. Tsimpidi acknowledges support from a DFG Individual Grant Programme (project reference TS 335/2-1).

The article processing charges for this open-access publication were covered by the Max Planck Society.

Edited by: Y. Balkanski

\section{References}

Adams, P. J., Seinfeld, J. H., and Koch, D. M.: Global concentrations of tropospheric sulfate, nitrate, and ammonium aerosol simulated in a general circulation model, J. Geophys. Res.-Atmos., 104, 13791-13823, doi:10.1029/1999jd900083, 1999.

Ames, R. B. and Malm, W. C.: Comparison of sulfate and nitrate particle mass concentrations measured by IMPROVE and the CDN, Atmos. Environ., 35, 905-916, 2001.

Ansari, A. S. and Pandis, S. N.: Prediction of multicomponent inorganic atmospheric aerosol behavior, Atmos. Environ., 33, 745757, 1999.

Ansari, A. S. and Pandis, S. N.: The effect of metastable equilibrium states on the partitioning of nitrate between the gas and aerosol phases, Atmos. Environ., 34, 157-168, 2000.

Astitha, M. and Kallos, G.: Gas-phase and aerosol chemistry interactions in South Europe and the Mediterranean region, Environ. Fluid Mech., 9, 3-22, 2009.

Astitha, M., Lelieveld, J., Abdel Kader, M., Pozzer, A., and de Meij, A.: Parameterization of dust emissions in the global atmospheric chemistry-climate model EMAC: impact of nudging and soil properties, Atmos. Chem. Phys., 12, 11057-11083, doi:10.5194/acp-12-11057-2012, 2012.

Athanasopoulou, E., Tombrou, M., Pandis, S. N., and Russell, A. G.: The role of sea-salt emissions and heterogeneous chemistry in the air quality of polluted coastal areas, Atmos. Chem. Phys., 8, 5755-5769, doi:10.5194/acp-8-5755-2008, 2008.

Athanasopoulou, E., Tombrou, M., Russell, A. G., Karanasiou, A., Eleftheriadis, K. and Dandou, A.: Implementation of road and soil dust emission parameterizations in the aerosol model CAMx: Applications over the greater Athens urban area affected by natural sources, J. Geophys. Res.-Atmo., 115, D17301, doi:10.1029/2009JD013207, 2010.

Bangert, M., Nenes, A., Vogel, B., Vogel, H., Barahona, D., Karydis, V. A., Kumar, P., Kottmeier, C., and Blahak, U.: Saharan dust event impacts on cloud formation and radiation over Western Europe, Atmos. Chem. Phys., 12, 4045-4063, doi:10.5194/acp-124045-2012, 2012.

Bauer, S. E., Balkanski, Y., Schulz, M., Hauglustaine, D. A., and Dentener, F.: Global modeling of heterogeneous chemistry on mineral aerosol surfaces: Influence on tropospheric ozone chemistry and comparison to observations, J. Geophys. Res.-Atmos., 109, D02304, doi:10.1029/2003jd003868, 2004.

Bellouin, N., Rae, J., Jones, A., Johnson, C., Haywood, J., and Boucher, O.: Aerosol forcing in the Climate Model Intercomparison Project (CMIP5) simulations by HadGEM2-ES and the role of ammonium nitrate, J. Geophys. Res.-Atmos., 116, D20206, doi:10.1029/2011jd016074, 2011.

Bian, H. S. and Zender, C. S.: Mineral dust and global tropospheric chemistry: Relative roles of photolysis and heterogeneous uptake, J. Geophys. Res.-Atmos., 108, 4672, doi:10.1029/2002jd003143, 2003.

Bouwman, A. F., Lee, D. S., Asman, W. A. H., Dentener, F. J., VanderHoek, K. W., and Olivier, J. G. J.: A global high-resolution emission inventory for ammonia, Global Biogeochem. Cy., 11, 561-587, 1997.

Capaldo, K. P., Pilinis, C., and Pandis, S. N.: A computationally efficient hybrid approach for dynamic gas/aerosol transfer in air quality models, Atmos. Environ., 34, 3617-3627, 2000. 
Chiapello, I., Moulin, C., and Prospero, J. M.: Understanding the long-term variability of African dust transport across the Atlantic as recorded in both Barbados surface concentrations and large-scale Total Ozone Mapping Spectrometer (TOMS) optical thickness, J. Geophys. Res., 110, D18S10, doi:10.1029/2004JD005132, 2005.

Dada, L., Mrad, R., Siffert, S., and Saliba, N. A.: Atmospheric markers of African and Arabian dust in an urban eastern Mediterranean environment, Beirut, Lebanon, J. Aerosol Sci., 66, 187192, doi:10.1016/j.jaerosci.2013.09.002, 2013.

D'Almeida, G. A.: On the variability of desert aerosol radiative characteristics, J. Geophys. Res., 92, 3017-3026, 1987.

de Meij, A., Pozzer, A., Pringle, K. J., Tost, H., and Lelieveld, J.: EMAC model evaluation and analysis of atmospheric aerosol properties and distribution with a focus on the Mediterranean region, Atmos. Res., 114, 38-69, 2012.

Dentener, F. J., Carmichael, G. R., Zhang, Y., Lelieveld, J., and Crutzen, P. J.: Role of mineral aerosol as a reactive surface in the global troposphere, J. Geophys. Res.-Atmos., 101, 2286922889, doi:10.1029/96jd01818, 1996.

Dentener, F., Kinne, S., Bond, T., Boucher, O., Cofala, J., Generoso, S., Ginoux, P., Gong, S., Hoelzemann, J. J., Ito, A., Marelli, L., Penner, J. E., Putaud, J.-P., Textor, C., Schulz, M., van der Werf, G. R., and Wilson, J.: Emissions of primary aerosol and precursor gases in the years 2000 and 1750 prescribed data-sets for AeroCom, Atmos. Chem. Phys., 6, 4321-4344, doi:10.5194/acp-64321-2006, 2006.

Doering, U., van Aardenne, J., Monni, S., Pagliari, V., Orlandini, L., and SanMartin, F.: CIRCE report D8.1.3 - Update of gridded emission inventories, addition of period 1990-2005 and the years 2010, 2015, 2050, Tech. rep. 036961, 2009.

Fairlie, T. D., Jacob, D. J., Dibb, J. E., Alexander, B., Avery, M. A., van Donkelaar, A., and Zhang, L.: Impact of mineral dust on nitrate, sulfate, and ozone in transpacific Asian pollution plumes, Atmos. Chem. Phys., 10, 3999-4012, doi:10.5194/acp-10-39992010, 2010.

Fantle, M. S., Tollerud, H., Eisenhauer, A., and Holmden, C.: The $\mathrm{Ca}$ isotopic composition of dust-producing regions: Measurements of surface sediments in the Black Rock Desert, Nevada, Geochim. Cosmochim. Ac., 87, 178-193, 2012.

Feng, Y. and Penner, J. E.: Global modeling of nitrate and ammonium: Interaction of aerosols and tropospheric chemistry, J. Geophys. Res.-Atmos., 112, D01304, doi:10.1029/2005jd006404, 2007.

Formenti, P., Andreae, M. O., Lange, L., Roberts, G., Cafmeyer, J., Rajta, I., Maenhaut, W., Holben, B. N., Artaxo, P., and Lelieveld, J.: Saharan dust in Brazil and Suriname during the Large-Scale Biosphere-Atmosphere Experiment in Amazonia (LBA) - Cooperative LBA Regional Experiment (CLAIRE) in March 1998, J. Geophys. Res.-Atmos., 106, 14919-14934, doi:10.1029/2000jd900827, 2001.

Formenti, P., Rajot, J. L., Desboeufs, K., Caquineau, S., Chevaillier, S., Nava, S., Gaudichet, A., Journet, E., Triquet, S., Alfaro, S., Chiari, M., Haywood, J., Coe, H., and Highwood, E.: Regional variability of the composition of mineral dust from western Africa: Results from the AMMA SOP0/DABEX and DODO field campaigns, J. Geophys. Res.-Atmos., 113, D00C13, doi:10.1029/2008jd009903, 2008.
Fountoukis, C. and Nenes, A.: ISORROPIA II: a computationally efficient thermodynamic equilibrium model for $\mathrm{K}^{+}$. $\mathrm{Ca}^{2+}-\mathrm{Mg}^{2+}-\mathrm{NH}_{4}^{+}-\mathrm{Na}^{+}-\mathrm{SO}_{4}^{2-}-\mathrm{NO}_{3}^{-}-\mathrm{Cl}^{-}-\mathrm{H}_{2} \mathrm{O}$ aerosols, Atmos. Chem. Phys., 7, 4639-4659, doi:10.5194/acp-7-4639-2007, 2007.

Fountoukis, C., Nenes, A., Sullivan, A., Weber, R., Van Reken, T., Fischer, M., Matías, E., Moya, M., Farmer, D., and Cohen, R. C.: Thermodynamic characterization of Mexico City aerosol during MILAGRO 2006, Atmos. Chem. Phys., 9, 2141-2156, doi:10.5194/acp-9-2141-2009, 2009.

Gaiero, D. M., Brunet, F., Probst, J.-L., and Depetris, P. J.: A uniform isotopic and chemical signature of dust exported from Patagonia: Rock sources and occurrence in southern environments, Chem. Geol., 238, 107-120, 2007.

Giannadaki, D., Pozzer, A., and Lelieveld, J.: Modeled global effects of airborne desert dust on air quality and premature mortality, Atmos. Chem. Phys., 14, 957-968, doi:10.5194/acp-14-9572014, 2014.

Gong, S. L., Barrie, L. A., and Blanchet, J. P.: Modeling sea-salt aerosols in the atmosphere .1. Model development, J. Geophys. Res.-Atmos., 102, 3805-3818, doi:10.1029/96jd02953, 1997.

Grini, A., Myhre, G., Zender, C. S., and Isaksen, I. S. A.: Model simulations of dust sources and transport in the global atmosphere: Effects of soil erodibility and wind speed variability, J. Geophys. Res., 110, D02205, doi:10.1029/2004JD005037, 2005.

Hauglustaine, D. A., Balkanski, Y., and Schulz, M.: A global model simulation of present and future nitrate aerosols and their direct radiative forcing of climate, Atmos. Chem. Phys., 14, 1103111063, doi:10.5194/acp-14-11031-2014, 2014.

Henze, D. K., Seinfeld, J. H., and Shindell, D. T.: Inverse modeling and mapping US air quality influences of inorganic $\mathrm{PM}_{2.5}$ precursor emissions using the adjoint of GEOS-Chem, Atmos. Chem. Phys., 9, 5877-5903, doi:10.5194/acp-9-5877-2009, 2009.

Hering, S. and Cass, G.: The magnitude of bias in the measurement of $\mathrm{PM}_{2.5}$ arising from volatilization of particulate nitrate from teflon filters, J. Air Waste Manage., 49, 725-733, 1999.

Hodzic, A., Bessagnet, B., and Vautard, R.: A model evaluation of coarse-mode nitrate heterogeneous formation on dust particles, Atmos. Environ., 40, 4158-4171, 2006.

Im, U.: Impact of sea-salt emissions on the model performance and aerosol chemical composition and deposition in the East Mediterranean coastal regions, Atmos. Environ., 75, 329-340, 2013.

IPCC (Intergovernmental Panel on Climate Change): The physical science basis. Contribution of working group I to the fifth assessment report of the intergovernmental panel on climate change, edited by: Stocker, T. F., Qin, D., Plattner, G.-K., Tignor, M., Allen, S. K., Boschung, J., Nauels, A., Xia, Y., Bex, V., and Midgley, P. M., Cambridge University Press, Cambridge, United Kingdom and New York, NY, USA, 2013.

Jacob, D. J.: Heterogeneous chemistry and tropospheric ozone, Atmos. Environ., 34, 2131-2159, 2000.

Jacobson, M. Z.: Studying the effects of calcium and magnesium on size-distributed nitrate and ammonium with EQUISOLV II, Atmos. Environ., 33, 3635-3649, 1999.

Jacobson, M. Z., Tabazadeh, A., and Turco, R. P.: Simulating equilibrium within aerosols and nonequilibrium between 
gases and aerosols, J. Geophys. Res.-Atmos., 101, 9079-9091, doi:10.1029/96jd00348, 1996.

Jöckel, P., Tost, H., Pozzer, A., Brühl, C., Buchholz, J., Ganzeveld, L., Hoor, P., Kerkweg, A., Lawrence, M. G., Sander, R., Steil, B., Stiller, G., Tanarhte, M., Taraborrelli, D., van Aardenne, J., and Lelieveld, J.: The atmospheric chemistry general circulation model ECHAM5/MESSy1: consistent simulation of ozone from the surface to the mesosphere, Atmos. Chem. Phys., 6, 50675104, doi:10.5194/acp-6-5067-2006, 2006.

Jöckel, P., Kerkweg, A., Pozzer, A., Sander, R., Tost, H., Riede, H., Baumgaertner, A., Gromov, S., and Kern, B.: Development cycle 2 of the Modular Earth Submodel System (MESSy2), Geosci. Model Dev., 3, 717-752, doi:10.5194/gmd-3-717-2010, 2010.

Kallos, G., Papadopoulos, A., Katsafados, P., and Nickovic, S.: Transatlantic Saharan dust transport: Model simulation and results, J. Geophys. Res., 111, D09204, doi:10.1029/2005jd006207, 2006.

Kallos, G., Astitha, M., Katsafados, P., and Spyrou, C.: Long-range transport of anthropogenically and naturally produced particulate matter in the Mediterranean and North Atlantic: Current state of knowledge, J. Appl. Meteorol. Clim., 46, 1230-1251, 2007.

Karydis, V. A., Tsimpidi, A. P., and Pandis, S. N.: Evaluation of a three-dimensional chemical transport model (PMCAMx) in the eastern United States for all four seasons, J. Geophys. Res.Atmos., 112, D14211, doi:10.1029/2006JD007890, 2007.

Karydis, V. A., Tsimpidi, A. P., Fountoukis, C., Nenes, A., Zavala, M., Lei, W., Molina, L. T., and Pandis, S. N.: Simulating the fine and coarse inorganic particulate matter concentrations in a polluted megacity, Atmos. Environ., 44, 608-620, 2010.

Karydis, V. A., Tsimpidi, A. P., Lei, W., Molina, L. T., and Pandis, S. N.: Formation of semivolatile inorganic aerosols in the Mexico City Metropolitan Area during the MILAGRO campaign, Atmos. Chem. Phys., 11, 13305-13323, doi:10.5194/acp11-13305-2011, 2011a.

Karydis, V. A., Kumar, P., Barahona, D., Sokolik, I. N., and Nenes, A.: On the effect of dust particles on global cloud condensation nuclei and cloud droplet number, J. Geophys. Res.-Atmos., 116, D23204, doi:10.1029/2011jd016283, 2011b.

Kasper-Zubillaga, J. J. and Zolezzi-Ruiz, H.: Grain size, mineralogical and geochemical studies of coastal and inland dune sands from El Vizcaino Desert, Baja California Peninsula, Mexico, Rev. Mex. Cienc. Geol., 24, 423-438, 2007.

Kerkweg, A., Buchholz, J., Ganzeveld, L., Pozzer, A., Tost, H., and Jöckel, P.: Technical Note: An implementation of the dry removal processes DRY DEPosition and SEDImentation in the Modular Earth Submodel System (MESSy), Atmos. Chem. Phys., 6, 4617-4632, doi:10.5194/acp-6-4617-2006, 2006.

Kerkweg, A., Sander, R., Tost, H., Jöckel, P., and Lelieveld, J.: Technical Note: Simulation of detailed aerosol chemistry on the global scale using MECCA-AERO, Atmos. Chem. Phys., 7, 2973-2985, doi:10.5194/acp-7-2973-2007, 2007.

Kim, Y. P. and Seinfeld, J. H.: Atmospheric gas-aerosol equilibrium 3. Thermodynamics of crustal elements $\mathrm{Ca}^{2+}, \mathrm{K}^{+}$, and $\mathrm{Mg}^{2+}$, Aerosol Sci. Tech., 22, 93-110, 1995.

Kim, Y. P., Seinfeld, J. H., and Saxena, P.: Atmospheric gas aerosol equilibrium. 1.Thermodynamic model, Aerosol Sci. Tech., 19, 157-181, 1993.

Koch, D., Bauer, S. E., Del Genio, A., Faluvegi, G., McConnell, J. R., Menon, S., Miller, R. L., Rind, D., Ruedy, R., Schmidt,
G. A., and Shindell, D.: Coupled Aerosol-Chemistry-Climate Twentieth-Century Transient Model Investigation: Trends in Short-Lived Species and Climate Responses, J. Climate, 24, 2693-2714, 2011.

Kopacz, M., Jacob, D. J., Fisher, J. A., Logan, J. A., Zhang, L., Megretskaia, I. A., Yantosca, R. M., Singh, K., Henze, D. K., Burrows, J. P., Buchwitz, M., Khlystova, I., McMillan, W. W., Gille, J. C., Edwards, D. P., Eldering, A., Thouret, V., and Nedelec, P.: Global estimates of CO sources with high resolution by adjoint inversion of multiple satellite datasets (MOPITT, AIRS, SCIAMACHY, TES), Atmos. Chem. Phys., 10, 855-876, doi:10.5194/acp-10-855-2010, 2010.

Laskin, A., Wietsma, T. W., Krueger, B. J., and Grassian, V. H.: Heterogeneous chemistry of individual mineral dust particles with nitric acid: A combined CCSEM/EDX, ESEM, and ICP-MS study, J. Geophys. Res.-Atmos., 110, D10208, doi:10.1029/2004jd005206, 2005.

Leibensperger, E. M., Mickley, L. J., Jacob, D. J., Chen, W.-T., Seinfeld, J. H., Nenes, A., Adams, P. J., Streets, D. G., Kumar, N., and Rind, D.: Climatic effects of 1950-2050 changes in US anthropogenic aerosols - Part 1: Aerosol trends and radiative forcing, Atmos. Chem. Phys., 12, 3333-3348, doi:10.5194/acp-12-33332012, 2012.

Liao, H., Adams, P. J., Chung, S. H., Seinfeld, J. H., Mickley, L. J., and Jacob, D. J.: Interactions between tropospheric chemistry and aerosols in a unified general circulation model, J. Geophys. Res.-Atmos., 108, 4001, doi:10.1029/2001jd001260, 2003.

Martin, R. V., Jacob, D. J., Yantosca, R. M., Chin, M., and Ginoux, P.: Global and regional decreases in tropospheric oxidants from photochemical effects of aerosols, J. Geophys. Res.-Atmos., 108, 4097, doi:10.1029/2002jd002622, 2003.

Meng, Z. Y. and Seinfeld, J. H.: Time scales to achieve atmospheric gas-aerosol equilibrium for volatile species, Atmos. Environ., 30, 2889-2900, 1996.

Metzger, S. and Lelieveld, J.: Reformulating atmospheric aerosol thermodynamics and hygroscopic growth into fog, haze and clouds, Atmos. Chem. Phys., 7, 3163-3193, doi:10.5194/acp-73163-2007, 2007.

Metzger, S., Dentener, F., Krol, M., Jeuken, A., and Lelieveld, J.: Gas/aerosol partitioning - 2. Global modeling results, J. Geophys. Res.-Atmos., 107, 4313, doi:10.1029/2001jd001103, 2002.

Michalski, G., Bohlke, J. K., and Thiemens, M.: Long term atmospheric deposition as the source of nitrate and other salts in the Atacama Desert, Chile: New evidence from mass-independent oxygen isotopic compositions, Geochim. Cosmochim. Ac., 68, 4023-4038, 2004.

Mitsakou, C., Kallos, G., Papantoniou, N., Spyrou, C., Solomos, S., Astitha, M., and Housiadas, C.: Saharan dust levels in Greece and received inhalation doses, Atmos. Chem. Phys., 8, 7181-7192, doi:10.5194/acp-8-7181-2008, 2008.

Moya, M., Pandis, S. N., and Jacobson, M. Z.: Is the size distribution of urban aerosols determined by thermodynamic equilibrium? An application to Southern California, Atmos. Environ., 36, 2349-2365, 2002.

Nenes, A., Pandis, S. N., and Pilinis, C.: ISORROPIA: A new thermodynamic equilibrium model for multiphase multicomponent inorganic aerosols, Aquat. Geochem., 4, 123-152, 1998.

Pozzer, A., Jöckel, P., Sander, R., Williams, J., Ganzeveld, L., and Lelieveld, J.: Technical Note: The MESSy-submodel AIRSEA 
calculating the air-sea exchange of chemical species, Atmos. Chem. Phys., 6, 5435-5444, doi:10.5194/acp-6-5435-2006, 2006.

Pozzer, A., Jöckel, P., and Van Aardenne, J.: The influence of the vertical distribution of emissions on tropospheric chemistry, Atmos. Chem. Phys., 9, 9417-9432, doi:10.5194/acp-9-9417-2009, 2009.

Pozzer, A., de Meij, A., Pringle, K. J., Tost, H., Doering, U. M., van Aardenne, J., and Lelieveld, J.: Distributions and regional budgets of aerosols and their precursors simulated with the EMAC chemistry-climate model, Atmos. Chem. Phys., 12, 961-987, doi:10.5194/acp-12-961-2012, 2012.

Price, C. and Rind, D.: A simple lightning parameterization for calculating global lightning distributions, J. Geophys. Res.-Atmos., 97, 9919-9933, 1992.

Pringle, K. J., Tost, H., Message, S., Steil, B., Giannadaki, D., Nenes, A., Fountoukis, C., Stier, P., Vignati, E., and Lelieveld, J.: Description and evaluation of GMXe: a new aerosol submodel for global simulations (v1), Geosci. Model Dev., 3, 391-412, doi:10.5194/gmd-3-391-2010, 2010.

Prospero, J. M., Olmez, I., and Ames, M.: Al and Fe in $\mathrm{PM}_{2.5}$ and $\mathrm{PM}_{10}$ suspended particles in south-central Florida: The impact of the long range transport of African mineral dust, Water Air Soil Pollut., 125, 291-317, 2001. Prospero, J. M., Ginoux, P., Torres, O., Nicholson, S. E., and Gill, T. E.: Environmental characterization of global sources of atmospheric soil dust identified with the Nimbus 7 Total Ozone Mapping Spectrometer (TOMS) absorbing aerosol product, Rev. Geophys., 40, 1002, doi:10.1029/2000rg000095, 2002.

Putaud, J. P., Raes, F., Van Dingenen, R., Bruggemann, E., Facchini, M. C., Decesari, S., Fuzzi, S., Gehrig, R., Huglin, C., Laj, P., Lorbeer, G., Maenhaut, W., Mihalopoulos, N., Mulller, K., Querol, X., Rodriguez, S., Schneider, J., Spindler, G., ten Brink, H., Torseth, K., and Wiedensohler, A.: European aerosol phenomenology-2: chemical characteristics of particulate matter at kerbside, urban, rural and background sites in Europe, Atmos. Environ., 38, 2579-2595, 2004.

Putaud, J. P., Van Dingenen, R., Alastuey, A., Bauer, H., Birmili, W., Cyrys, J., Flentje, H., Fuzzi, S., Gehrig, R., Hansson, H. C., Harrison, R. M., Herrmann, H., Hitzenberger, R., Hueglin, C., Jones, A. M., Kasper-Giebl, A., Kiss, G., Kousa, A., Kuhlbusch, T. A. J., Loeschau, G., Maenhaut, W., Molnar, A., Moreno, T., Pekkanen, J., Perrino, C., Pitz, M., Puxbaum, H., Querol, X., Rodriguez, S., Salma, I., Schwarz, J., Smolik, J., Schneider, J., Spindler, G., ten Brink, H., Tursic, J., Viana, M., Wiedensohler, A., and Raes, F.: A European aerosol phenomenology-3: Physical and chemical characteristics of particulate matter from 60 rural, urban, and kerbside sites across Europe, Atmos. Environ., 44, 1308-1320, 2010.

Querol, X., Pey, J., Pandolfi, M., Alastuey, A., Cusack, M., Perez, N., Moreno, T., Viana, M., Mihalopoulos, N., Kallos, G., and Kleanthous, S.: African dust contributions to mean ambient $\mathrm{PM}_{10}$ mass-levels across the Mediterranean Basin, Atmos. Environ., 43, 4266-4277, 2009.

Radhi, M., Box, M. A., Box, G. P., Keywood, M. D., Cohen, D. D., Stelcer, E., and Mitchell, R. M.: Size-resolved chemical composition of Australian dust aerosol during winter, Environ. Chem., 8, 248-262, 2011.
Resane, T., Annegarn, H., and Freiman, T.: The day of the white rain: origin of unusual dust deposition in Johannesburg, South Africa, S. Afr. J. Sci., 100, 483-487, 2004.

Reynolds, R. L., Reheis, M., Yount, J., and Lamothe, P.: Composition of aeolian dust in natural traps on isolated surfaces of the central Mojave Desert - Insights to mixing, sources, and nutrient inputs, J. Arid Environ., 66, 42-61, 2006.

Rodriguez, M. A. and Dabdub, D.: A modeling study of size- and chemically resolved aerosol thermodynamics in a global chemical transport model, J. Geophys. Res.-Atmos., 109, D02203, doi:10.1029/2003jd003639, 2004.

Roeckner, E., Brokopf, R., Esch, M., Giorgetta, M., Hagemann, S., Kornblueh, L., Manzini, E., Schlese, U., and Schulzweida, U.: Sensitivity of simulated climate to horizontal and vertical resolution in the ECHAM5 atmosphere model, J. Climate, 19, 37713791, doi:10.1175/jcli3824.1, 2006.

Sander, R., Baumgaertner, A., Gromov, S., Harder, H., Jöckel, P., Kerkweg, A., Kubistin, D., Regelin, E., Riede, H., Sandu, A., Taraborrelli, D., Tost, H., and Xie, Z.-Q.: The atmospheric chemistry box model CAABA/MECCA-3.0, Geosci. Model Dev., 4, 373-380, doi:10.5194/gmd-4-373-2011, 2011.

Savoie, D. L. and Prospero, J. M.: Particle-Size Distribution of Nitrate and Sulfate in he Marine Atmosphere, Geophys. Res. Lett., 9, 1207-1210, 1982.

Seinfeld, J. H. and Pandis, S. N.: Atmo. Chem. Phys.: From Air Pollution to Climate Change, 2nd Edn., John Wiley \& Sons, Inc., Hoboken, New Jersey, 2006.

Solmon, F., Chuang, P. Y., Meskhidze, N., and Chen, Y.: Acidic processing of mineral dust iron by anthropogenic compounds over the north Pacific Ocean, J. Geophys. Res., 114, D02305, doi:10.1029/2008JD010417, 2009.

Solomon, P., Norris, G., Landis, M., and Tolocka, M.: Chemical analysis methods for atmospheric aerosol components, in Aerosol Measurement: Principles, Techniques, and Applications, edited by: Baron, P. A. and Willeke, K., 261-294, John Wiley, Hoboken, N.J., 2001.

Song, C. H. and Carmichael, G. R.: A three-dimensional modeling investigation of the evolution processes of dust and sea-salt particles in east Asia, J. Geophys. Res.-Atmos., 106, 18131-18154, doi:10.1029/2000jd900352, 2001.

Sposito, G.: The Chemistry of Soils, Oxford University Press, 1989. ten Brink, H. M., Kruisz, C., Kos, G. P. A., and Berner, A.: Composition/size of the light-scattering aerosol in The Netherlands, Atmos. Environ., 31, 3955-3962, 1997.

Tost, H., Jöckel, P., Kerkweg, A., Sander, R., and Lelieveld, J.: Technical note: A new comprehensive SCAVenging submodel for global atmospheric chemistry modelling, Atmos. Chem. Phys., 6, 565-574, doi:10.5194/acp-6-565-2006, 2006.

Tost, H., Jöckel, P., Kerkweg, A., Pozzer, A., Sander, R., and Lelieveld, J.: Global cloud and precipitation chemistry and wet deposition: tropospheric model simulations with ECHAM5/MESSy1, Atmos. Chem. Phys., 7, 2733-2757, doi:10.5194/acp-7-2733-2007, 2007.

Tripaldi, A., Ciccioli, P. L., Susana Alonso, M., and Forman, S. L.: Petrography and geochemistry of late Quaternary dune fields of western Argentina: Provenance of aeolian materials in southern South America, Aeolian Research, 2, 33-48, 2010.

Trump, E. R., Fountoukis, C., Donahue, N. M., and Pandis, S. N.: Improvement of simulation of fine inorganic PM levels through 
better descriptions of coarse particle chemistry, Atmos. Environ., 102, 274-281, 2015.

Tsyro, S., Aas, W., Soares, J., Sofiev, M., Berge, H., and Spindler, G.: Modelling of sea salt concentrations over Europe: key uncertainties and comparison with observations, Atmos. Chem. Phys., 11, 10367-10388, doi:10.5194/acp-11-10367-2011, 2011.

Veefkind, J. P., vanderHage, J. C. H., and tenBrink, H. M.: Nephelometer derived and directly measured aerosol optical depth of the atmospheric boundary layer, Atmos. Res., 41, 217-228, 1996.

Vignati, E., Wilson, J., and Stier, P.: M7: An efficient sizeresolved aerosol microphysics module for large-scale aerosol transport models, J. Geophys. Res.-Atmos., 109, D22202, doi:10.1029/2003jd004485, 2004.

Wang, K., Zhang, Y., Nenes, A., and Fountoukis, C.: Implementation of dust emission and chemistry into the Community Multiscale Air Quality modeling system and initial application to an Asian dust storm episode, Atmos. Chem. Phys., 12, 10209 10237, doi:10.5194/acp-12-10209-2012, 2012.

Wexler, A. S. and Seinfeld, J. H.: 2nd Generation Inorganic aerosol model, Atmos. Environ. A-Gen., 25, 2731-2748, 1991

Wolff, G. T.: On the nature of nitrate in coarse continental aerosols, Atmos. Environ., 18, 977-981, 1984.
Xu, L. and Penner, J. E.: Global simulations of nitrate and ammonium aerosols and their radiative effects, Atmos. Chem. Phys., 12, 9479-9504, doi:10.5194/acp-12-9479-2012, 2012.

Yadav, S. and Rajamani, V.: Geochemistry of aerosols of northwestern part of India adjoining the Thar Desert, Geochim. Cosmochim. Ac., 68, 1975-1988, 2004.

Yienger, J. J. and Levy, H.: Empirical model of global soil-biogenic $\mathrm{NO}_{x}$ emissions, J. Geophys. Res.-Atmos., 100, 11447-11464, 1995.

Zender, C. S. and Kwon, E. Y.: Regional contrasts in dust emission responses to climate, J. Geophys. Res., 110, D13201, doi:10.1029/2004JD005501, 2005.

Zender, C. S., Bian, H. S., and Newman, D.: Mineral Dust Entrainment and Deposition (DEAD) model: Description and 1990s dust climatology, J. Geophys. Res.-Atmos., 108, 4416, doi:10.1029/2002jd002775, 2003.

Zhang, X. Y., Gong, S. L., Shen, Z. X., Mei, F. M., Xi, X. X., Liu, L. C., Zhou, Z. J., Wang, D., Wang, Y. Q., and Cheng, Y.: Characterization of soil dust aerosol in China and its transport and distribution during 2001 ACE-Asia. 1. Network observations, J. Geophys. Res., 108, 4261, doi:10.1029/2002jd002632, 2003. 